\title{
The incrementally zoned Miocene Ayagaures ignimbrite (Gran Canaria, Canary Islands)
}

\author{
Martin Jutzeler ${ }^{\mathrm{a}, *}$, Hans-Ulrich Schmincke ${ }^{\mathrm{b}}$, Mari Sumita ${ }^{\mathrm{b}}$ \\ a Institute of Mineralogy and Geochemistry, University of Lausanne, Switzerland \\ ${ }^{\mathrm{b}}$ Leibniz-Institut für Meereswissenschaften (IFM-Geomar), Kiel, Germany
}

\section{A R T I C L E I N F O}

Article history:

Received 31 December 2009

Accepted 3 July 2010

Available online 16 July 2010

\section{Keywords:}

Ignimbrite

flow unit

cooling unit

Phonolite

highly welded

Incremental zoning

Caldera collapse

Gran Canaria

Canary Islands

\begin{abstract}
A B S T R A C T
The 20-25 m thick trachyphonolitic Ayagaures ignimbrite cooling unit [(AY); $11.8 \mathrm{Ma}$ ] exposed over $250 \mathrm{~km}^{2}$ (onshore volume ca. $4.5 \mathrm{~km}^{3} \mathrm{DRE}$ ) is the uppermost and most voluminous cooling unit of the Middle Fataga Formation (MFF), part of the Fataga Group (ca. 13.3-ca. 9 Ma) on Gran Canaria (GC), Canary Islands $\left(28^{\circ} 00^{\prime} \mathrm{N}, 15^{\circ} 35^{\prime} \mathrm{W}\right)$. Up to 19 flow units (named $\mathrm{b}-\mathrm{t}$ ) subdividing the AY have been identified throughout most of the area from proximally to the caldera wall to distally as far as $14 \mathrm{~km}$ away. Individual flow units were distinguished from each other and logged using mainly chemical criteria. Single and/or packages of flow units (A, B and C) are tentatively interpreted to correspond to compositionally distinct magma bodies erupted from the same magma reservoir. These source-controlled flow units are interpreted to reflect successive eruptive pulses during incremental subsidence of Tejeda caldera.

We subdivided AY cooling unit into four welding facies. Tentative correlation with a major syn-ignimbrite turbidite drilled during ODP Leg 157 suggests a total DRE volume of $>50 \mathrm{~km}^{3}$.

The cooling unit as a whole becomes less evolved upwards as shown by major elements, trace elements and REE of bulk rock and phenocrysts. All phenocryst phases, dominantly sanidine-anorthoclase (up to 20 vol.\%), with minor biotite, augite, titanite, haüyne and apatite, are unzoned and show an incremental compositional zoning in the stratigraphy. The shallow level parent magma reservoir is interpreted to have undergone strong mixing prior to starting its final compositional zoning in a thermodynamically equilibrated reservoir. Compositional zoning resulted in three main bodies. This compositional and physical layering may have been triggered by rapid growth of alkali feldspar and biotite throughout the erupted part of the magma chamber. Abundant titanite and haüyne phenocrysts in basal flow units and in a locally preserved, highly evolved fallout tephra are interpreted to reflect initial evacuation of a small volume, highly fractionated cupola. AY represents the most evolved part of a large, partially evacuated magma reservoir. Progressive downward tapping of the reservoir is interpreted to have been controlled by incremental caldera collapse. Absence of less evolved magmas suggests that the magma chamber was only partially evacuated. Incremental compositional zoning of the cooling unit, but unzoned phenocrysts and evacuation reversals show that mixing did not occur following initiation of alkali feldspar growth.
\end{abstract}

(c) 2010 Elsevier B.V. All rights reserved.

\section{Introduction}

The Miocene ignimbrites of Gran Canaria (GC), Canary Islands, erupted over some 5 million years from the ca. $20 \mathrm{~km}$ Tejeda caldera. Two major compositional groups have been distinguished from each other; the subalkaline to peralkaline dominantly rhyolitic Mogán Group, comprising three formations and a total of at least 15 ignimbrite members (14-13.3 Ma) and the trachyphonolitic to phonolitic Fataga Group (ca. 13.3-8.6 Ma) comprising four formations (Schmincke, 1976,

\footnotetext{
* Corresponding author. CODES-ARC Centre of Excellence in Ore Deposits, University of Tasmania, Private Bag 79, Hobart, TAS, 7001, Australia. Tel.: +61 36226 2376; fax: +61362267662.

E-mail address: jutzeler@gmail.com (M. Jutzeler).
}

1982; Schmincke and Sumita, 1998b, a; Schmincke, 2004; Schmincke and Sumita, 2010). In contrast to the Mogán Group, which contains only one major lava flow near the base, thick lavas flows have been erupted throughout most of Fataga Group evolution, dominating the area east of Fataga Canyon in southeastern Gran Canaria (Schmincke, 1969; Schmincke and Sumita, 1998a,b).

Ignimbrites of the Mogán and Fataga Groups are typically 5 to $40 \mathrm{~m}$ thick, strongly welded and compacted cooling units. The Ayagaures ignimbrite (AY), one of the most prominent ignimbrites of the Fataga Group, differs in many respects from the rhyolitic Mogán Group ignimbrites which have been previously studied in depth (Freundt and Schmincke, 1995a; Kobberger and Schmincke, 1999; Troll and Schmincke, 2002). The AY was recognized in the field by several distinctive features, including its impressive thickness, its compaction features (shearing planes, flattened fiamme), a slightly bluish matrix, 
and presence of white secondary minerals of deuteric origin in the most compacted part of the cooling unit.

Here we present a detailed macroscopic, microscopic and compositional (bulk rock and mineral chemistry) analysis of AY. Our goal is to better understand the compositional zoning in the magma reservoir, the magma evolution, and to reconstruct the eruptive and emplacement dynamics and subsequent cooling history of a trachyphonolitic ignimbrite. The excellent outcrops in southern Gran Canaria allow high-resolution correlation of flow units in ignimbrite cooling units and thus step-by-step analysis of the evolution of individual volcano-magma systems.

\section{Geological setting}

The $45-\mathrm{km}$-diameter Gran Canaria Island $\left(28^{\circ} 00^{\prime} \mathrm{N}, 15^{\circ} 35^{\prime} \mathrm{W}\right)$ is situated $200 \mathrm{~km}$ from the northwestern coast of Africa, and is one of the 2 central islands of the Canary Island archipelago (Fig. 1; Schmincke and Sumita, 2010). Growth of the 15-16 Ma old shield volcano complex of dominantly mildly alkaline basaltic lava flows, probably composed of 4 overlapping shield edifices (Krastel and Schmincke, 2002), was followed initially by more than 5 million years of chiefly ignimbrite eruptions, issued from the $20 \mathrm{~km}$ Tejeda caldera. Drilling of the volcanic apron of Gran Canaria showed that the submarine equivalents of the pyroclastic flows are more voluminous than their subaerial counterparts (Schmincke and Sumita, 1998a,b; Sumita and Schmincke, 1998). The total magma mass erupted between ca. 14 and $8.5 \mathrm{Ma}$ may have amounted to more than $1000 \mathrm{~km}^{3}$, building up a pile locally more than $500 \mathrm{~m}$ thick on top of the shield basalts that, in the northeastern half of the island, had been deeply eroded prior to emplacement of the pyroclastic flows. Erosion has been most severe in northeastern Gran Canaria because of constant trade wind directions since the Miocene. The Ayagaures

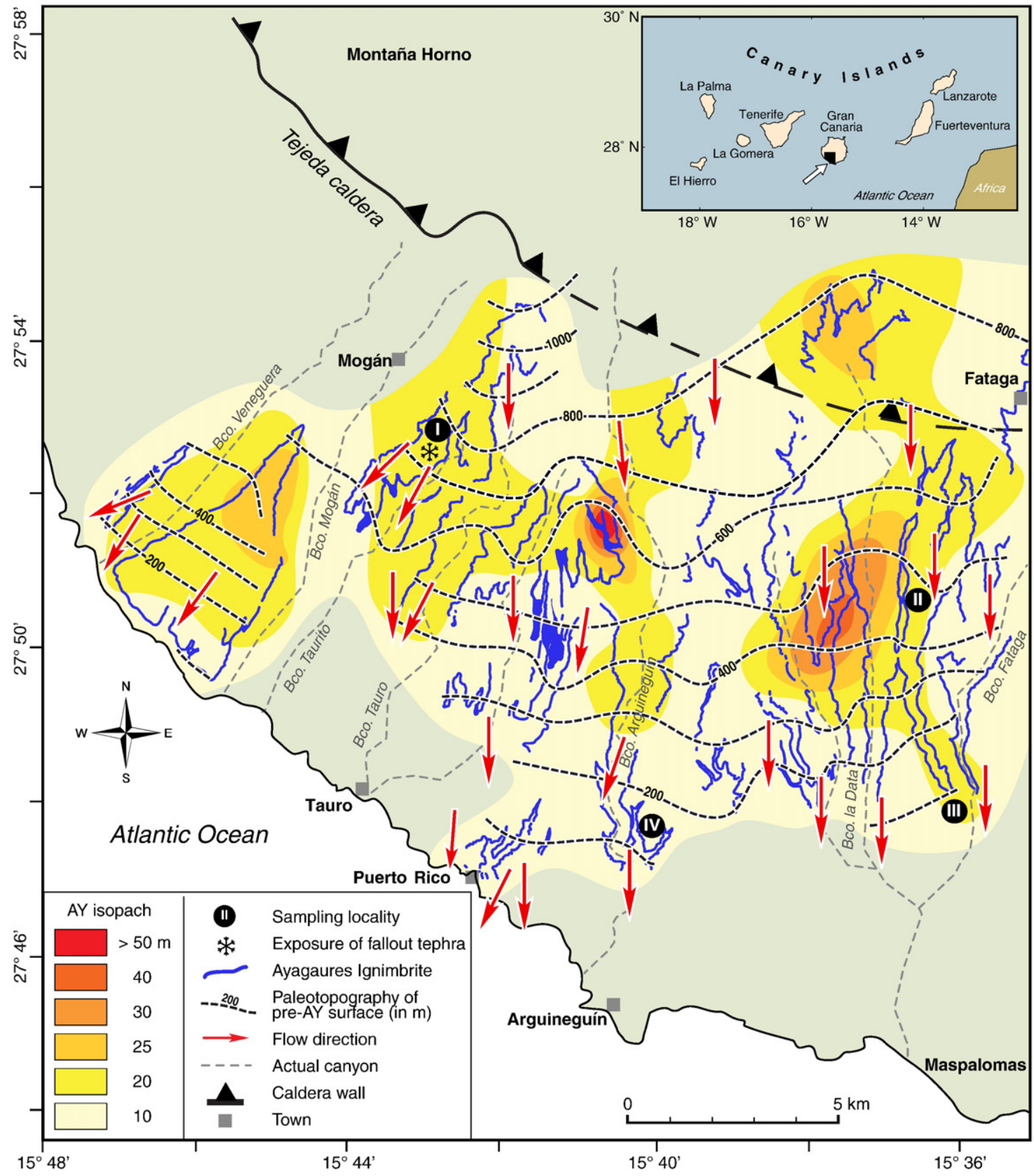

Fig. 1. Areal extent and thickness of Ayagaures ignimbrite, Gran Canaria (Canary Islands). Sampling localities, reconstructed paleotopography and flow directions are shown. 
Ignimbrite (AY), previously studied in reconnaissance fashion (Schmincke, 1987; Schmincke and Sumita, 2004), is the uppermost and largest unit of the Middle Fataga Formation (MFF) that comprises at least 6 ignimbrites. AY is overlain by the widespread Monte Leon Formation that is mainly composed of debris avalanche and lahar deposits, fluvial sediments, minor ignimbrites and fallout tephra generated over ca. 1 million years. This suggests that the eruption of AY represents the terminal event of a major eruptive interval during the evolution of the long-lasting Fataga Group history (Schmincke and Sumita, 2004).

\section{Methods and terminology}

Compaction, welding and recrystallization do not allow to precisely distinguish between fiamme and ash. For this reason, we do not use the term "ash" as it is reserved to describe a size-class $(<2 \mathrm{~mm})$ and would include small phenocrysts. Here, we use the term "matrix" to describe the very fine-grained $(<0.1 \mathrm{~mm})$, phenocryst-free, recrystallized particle mixture, dominantly former glass shards in AY, generally appearing dark in thin section.

A component size distribution technique could not be applied due to welding and compaction of the deposit. However, field and laboratory point-counting data were compiled to estimate volumetric amounts of various components. Fiamme, matrix, alkali feldspar phenocrysts and lithic fragments were distinguished from each other. Our methods include (a) estimates of the amount of oversized clasts on outcrops ( $>80 \mathrm{~mm}$ ), (b) 1000 points in a 1-meter vertical section (every $\mathrm{mm}$ ) on a representative outcrop and (c) a grid of 2000 points per microscopic study of thin sections. Volume amounts were normalized to DRE (Dense Rock Equivalent) to compensate for vesicularity. Trace phenocryst amounts were counted over a $20 \times 35 \mathrm{~mm}$ thin section. Bulk densities of the fiamme were calculated from an average of 2-4 samples per flow unit; the samples were volumetrically measured and weighed after drying at $110^{\circ} \mathrm{C}$.

Localities are in capital Roman numbers (I, II, III and IV). We use the term cooling unit as defined by Smith (1960) for the simultaneously cooled ignimbrite rock body. The AY cooling unit is subdivided into smaller units, called flow units, based on several characteristics such as grain size, grading, abrupt boundaries, etc. as detailed in the text. These units can be of two major types: source-controlled and emplacementcontrolled flow units (Wilson and Hildreth, 2003; Schmincke, 2004). While logging stratigraphic sections in the field, we have consecutively numbered the flow units with suffixes $(1,2,3$, etc.), only with respect to the local stratigraphy; in locality I, the largest number of such units is 12. Correlation based on field evidence, component volumes and geochemical trends allowed to reconstruct a regional stratigraphy of sourcecontrolled flow units, labeled with the letters $b$ to $t$, and arranged in three major compositional groups A, B and C.

Samples were chemically analyzed using a Philips PW 2400 X-ray fluorescence spectrometer at the University of Lausanne. The samples were ground in a tungsten carbide mill and then mixed with a proportional amount of lithium tetraborate to lower the melting point. Major element analyses were done on twice-melted glass beads in order to increase their homogeneity. We do not make use of the elements $\mathrm{Ta}, \mathrm{Co}$, and $\mathrm{Cr}$ as these may become modified when using a tungsten carbide mill. The material analyzed was preferentially single fiamme; where lacking, fiamme-rich and lithic-free bulk rocks were taken.

Electron-microprobe (EMP) analyses were carried out by a CAMECA SX50 at the University of Lausanne. An acceleration voltage of $15 \mathrm{kV}$ was used; beam current and exposure time depended on the element. Crystal and glass were analyzed on 120-micron-thick polished sections. Glass analyses were done with a current minimizing Na-migration, while keeping a sufficient amount of counts for accuracy.
LA-ICP-MS analyses were carried out at the University of Lausanne on an ICP-MS Perkin Elmer 6100 DRC, coupled with a Lambda Physik, Excimer ArF 193 nm laser. Laser beam diameter varied from 20 to $120 \mu \mathrm{m}$. Forty elements were analyzed on 120 -micron-thick polished sections (glass and phenocrysts). Trace elements of fiamme and bulk rock were analyzed on glass beads and averaged from a minimum of 2 analyses. LA-ICP-MS ratios were calibrated with EMP data; $\mathrm{Sr}$ was used as a standard for glass beads of bulk rock, whereas $\mathrm{Al}_{2} \mathrm{O}_{3}$ was used for alkali feldspar, biotite, glass and matrix; $\mathrm{CaO}$ for clinopyroxene and titanite.

\section{Lithology}

\subsection{Regional distribution, volume and lithology of $A Y$}

Fataga Group cooling units are well-exposed in southern GC. Lower MFF ignimbrites have partially filled paleo-valleys developed on the underlying morphologically highly uneven phonolitic lava flow surfaces, thus creating a generally smooth topography for the MFF ignimbrite cooling units on gentle slopes. AY was mapped over some $250 \mathrm{~km}^{2}$ (Fig. 1) and appears conformable everywhere with the MFF stratigraphy. It mantles topography, fills km-wide smooth paleovalleys and always starts with a sharp base (Fig. 2).

The pre-AY topography was reconstructed from the base of the ignimbrite (Fig. 1). Paleo-contour lines show a gentle $4.5^{\circ}$ to $5^{\circ}$ slope, which are broken by large paleo-valleys centered on barrancos (Bco.) de la Data, Arguineguín and Mogán. Current topographic highs show slightly higher slope gradients than in the Miocene. AY may once have covered the entire extracaldera slopes of the island, at least in the south. The original onland volume is estimated to have been $27 \mathrm{~km}^{3}$ DRE. Erosion during the main volcanic hiatus during the island's evolution (8.5-5 Ma) probably removed deposits on the $\mathrm{N}$ and $\mathrm{E}$ sides of GC. Tentative correlation between the 1-15-m-thick coastal outcrops and distal facies of eruption-fed "synignimbrite turbidites" drilled during ODP Leg 157 (Schmincke and Sumita, 1998b; Sumita and Schmincke, 1998) suggests that Ayagaures pyroclastic flows must have entered the sea over a broad sector and a total erupted magma volume of $>50 \mathrm{~km}^{3}$ DRE is estimated.

The westernmost outcrops, extending to the coast, are locally underlain by remobilized pre-ignimbrite tephra-fall. Although prevailing winds would have favored deposition in the studied area corresponding to the S and SW of the caldera (Schmincke, 2004) - we have noted a general absence of basal fall deposits beneath most Mogán and Fataga ignimbrites throughout southern Gran Canaria, except for widespread fall deposits at the base of ignimbrite VI (Mogán Group) and preservation in local morphologically favorable spots close to the caldera wall such as in upper Bco. de Mogán and near Agüimes (Schmincke, 1976, Schmincke and Sumita, unpubl.). Most likely, initial fallout layers were regionally eroded by the pyroclastic density currents, except for local morphological traps.

The northern and eastern sides of the island were not mapped, due to poor exposure and strong erosion of the Miocene deposits; southern outcrops are buried under Quaternary epiclastic sediments. Medial outcrops near Tauro and Puerto Rico (SW) are characterized by eroded, thin and red-oxidized cooling unit facies. AY was sampled in detail at 4 localities [I to IV (Fig. 1)]. Situated in the western part of the island, locality I represents a proximal facies $(\sim 5 \mathrm{~km}$ from caldera rim). Localities II, III and IV are situated in southern GC. II is a proximal extracaldera deposit $(<4 \mathrm{~km})$; III and IV are considered as medial by their distance to the caldera rim $(>10 \mathrm{~km})$.

AY thickness - i.e. post-compaction, eroded deposit thickness - was measured by tape and estimated by comparison with visual references. The top of AY has been eroded everywhere prior to deposition of the Monte Leon Formation. AY, on average $20-25 \mathrm{~m}$ thick, reaches $40 \mathrm{~m}$ in the south and up to $60 \mathrm{~m}$ in upper Bco. de Arguineguín (Figs. 1 and 2). The isopach pattern mimics the depth of valley filling. In areas such as 

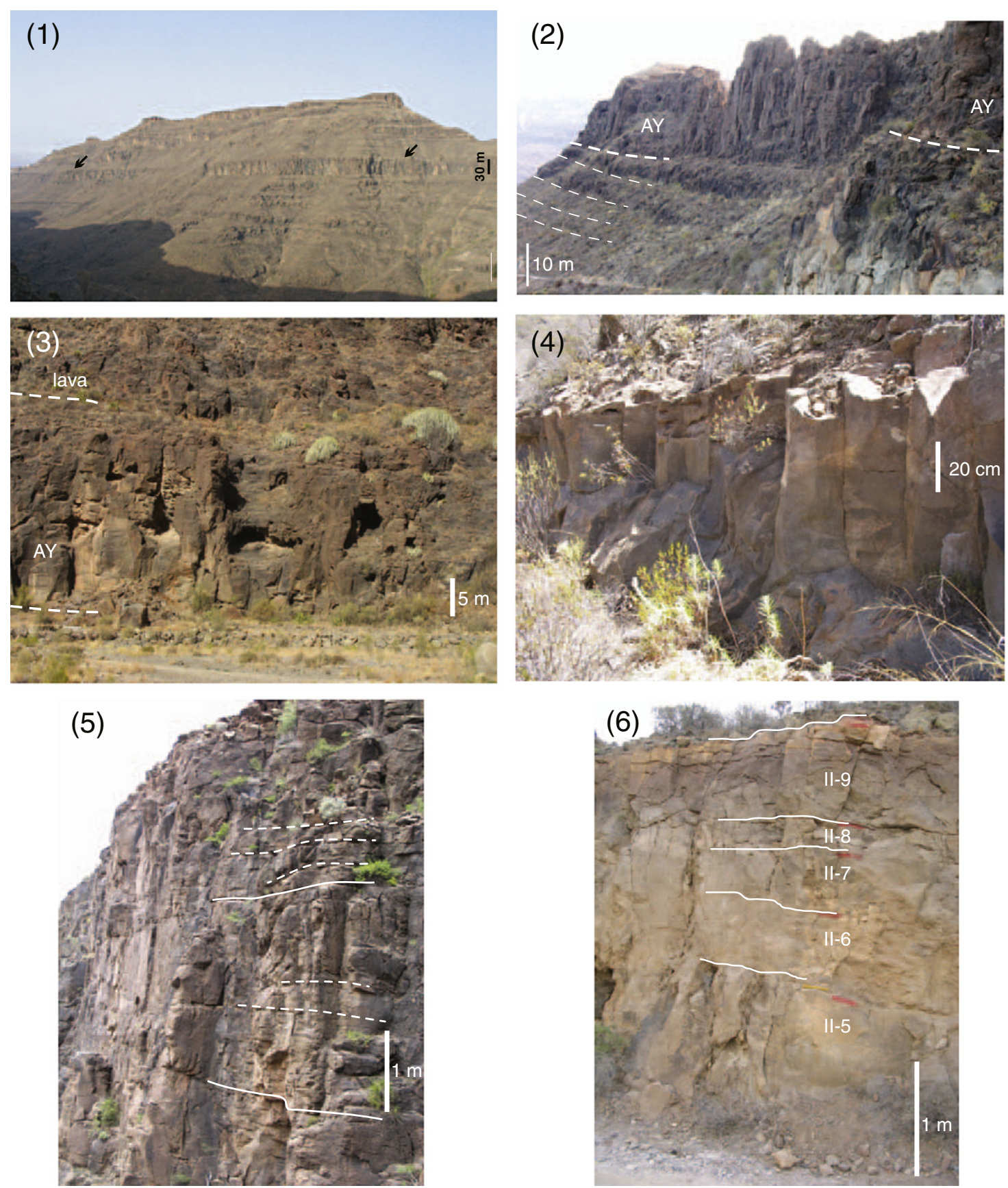

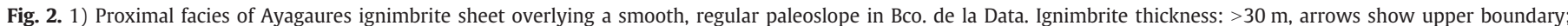

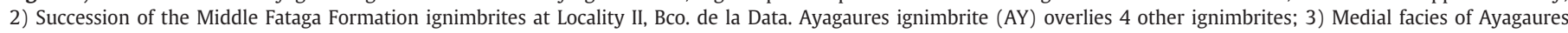

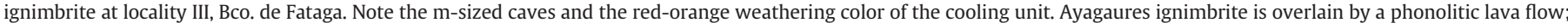

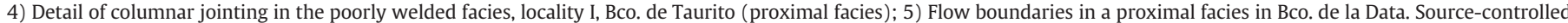

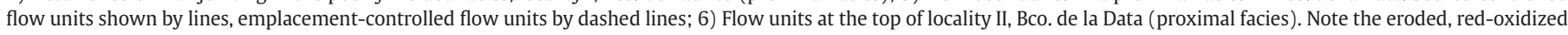
top.

Bco. de Arguineguín, Bco. de Fataga and Bco. de la Data, wide paleovalleys show large, smooth depressions, which indicate that AY did not completely fill the paleo-valleys, or that deflation was more intense in the valley axis.

Flattened fiamme, especially in the most compacted zone of the cooling unit, reflect the last movement of flow as it deflated, compacted and welded (Schmincke and Swanson, 1967). The direction of long axes of fiamme was measured in the field at many localities and shows that transport directions of AY are generally perpendicular to the inferred caldera rim and are identical in topographic highs and lows (Fig. 1). The main flow directions are S, and SW to WSW, roughly corresponding to the orientation of the actual canyons and indicate that the pyroclastic density currents traveled in a radially oriented drainage system practically identical to transport directions measured in Mogán Group ignimbrites (Schmincke and Swanson, 1967).

\subsection{Welding facies}

The AY cooling unit is subdivided into four welding facies (Fig. 3). These are defined by textural differences in compaction, welding and 


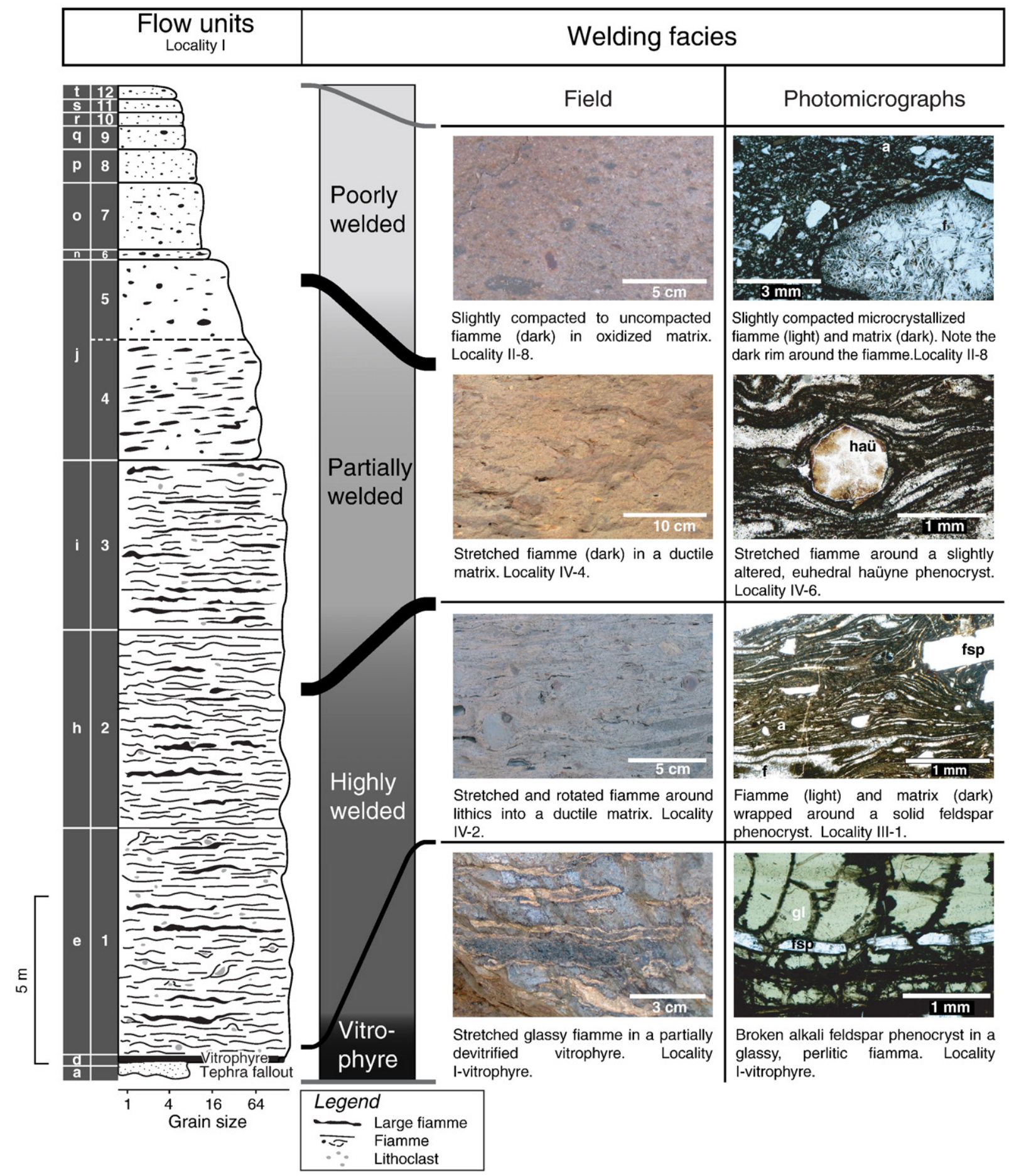

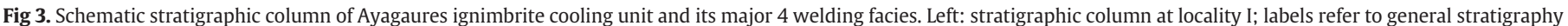
of Fig. 13; the width of the log corresponds to the average grain size, in mm. Photomicrographs are in plane polarized light.

post-emplacement crystallization described below. The compaction and welding criteria used are similar to those described from Mogán ignimbrite D (Kobberger and Schmincke, 1999) and Rattlesnake Tuff, USA (Streck and Grunder, 1995). Welding facies are completely gradational and the entire deposit shows a gradual decrease in compaction features upwards. The most compacted facies tend to overprint the emplacement-controlled flow unit boundaries (Fig. 2).

The basal facies of AY is represented by a $15-30 \mathrm{~cm}$ highly welded vitrophyre (Fig. 3). The most common facies comprises $20-50-\mathrm{cm}-$ long vitrophyric sections of massive, perlitic, largely devitrified glass. Strongly flattened fiamme textures are locally preserved in a more altered matrix; alkali feldspars show truncation joints due to the vertical compaction. A gradational transition marks the boundary with the highly welded facies. The boundary is accompanied by typically thin, 50-cm-long, low-angle domains of glassy vitrophyre penetrating the devitrified highly welded facies.

A 5-10 m thick, dense, highly welded deposit with a eutaxitic fabric overlies the basal vitrophyre (Fig. 3). Thin horizontal, m-scale 
stretched surfaces have dissected the deposit into several shear planes; scattered dm-scale parataxitic textures (rheomorphic folds) occur locally. Lithoclasts and alkali feldspars behaved as solids in a ductile matrix of deformed and compacted fiamme and finer-grained components. Lithoclasts are rimmed by rotational shear marks and pressure shadows (Schmincke and Swanson, 1967), whereas fiamme are preferentially flattened. White secondary tridymite and zeolites (wellite and merlinoite) commonly replace porosity in small fiamme of this facies.

Partially welded and compacted ignimbrite dominates this 15-20m-thick facies (Fig. 3). The eutaxitic texture is well-defined; fiamme and matrix can be easily distinguished from each other. Fiamme porosity becomes more apparent, whereas rotation and shear features are absent. This facies is characterized by m-size caves blanketed by macroscopic gypsum. Columnar joints are present in the top of this facies.

The top of the cooling unit consists of poorly welded and uncompacted ignimbrite ( $\sim 5 \mathrm{~m}$ thick) with partial erosion (Fig. 3). Clasts are randomly oriented and undeformed in the porous deposit. The red-orange color of the columnar jointed top is a result of hightemperature oxidation.

Bulk rock density (lithic-free) was measured for each flow unit in stratigraphic sections and is used as a proxy to describe the degree of compaction and welding of the deposit. The fallout layer - where present - is unwelded and uncompacted $\left(1.6 \mathrm{~g} / \mathrm{cm}^{3}\right)$ and is immediately followed by the compacted and highly welded $\left(2.4 \mathrm{~g} / \mathrm{cm}^{3}\right)$ vitrophyre [vitrophyre facies (Fig. 4)]. Compaction and welding increase up section within the lower $1 / 5$ of the cooling unit (above the vitrophyre to $5-7 \mathrm{~m}$ up), passing from moderately $\left(2.1 \mathrm{~g} / \mathrm{cm}^{3}\right)$ to highly compacted and welded level $\left(2.6 \mathrm{~g} / \mathrm{cm}^{3}\right)$. Higher up, the degree of compaction and welding gradually decreases stratigraphically upward as the bulk rock density reaches $1.7 \mathrm{~g} / \mathrm{cm}^{3}$ at the top of the partially welded facies of locality I. Flattening ratios (length/thickness) are measured through large fiamme. They decrease from 60 to 1 up section, without following the local positive density peak of the highly welded facies. The flattening ratio decreases upwards by almost two orders of magnitude for both large and small fiamme, and is reflected in changing shapes of vesicles in the fiamme. In the lowermost flow unit, vesicles are absent. Ellipsoidal vesicles appear first in the lower facies and the shape gradually changes to spherical upwards.

\subsection{Flow units}

The use of the term "flow unit" in this study refers only to a widespread, mappable (i.e. source-controlled) tabular rock body. Smallscale, laterally discontinuous depositional features likely due to emplacement-controlled flow units have not documented in our stratigraphic section. The detailed compositional (bulk rock and mineral chemistry) characterization of source-controlled units provides important information on compositional layering in the magma reservoir and the incremental discharge of magma volumes. Source-controlled flow units can be mapped and correlated over large distances, ideally to the caldera wall. They were systematically sampled at 4 localities where their color, weathering, clast vol.\%, clast size and flattening ratio were recorded. We were able to correlate many flow units (labeled $b$ to $t$ ) between 2 or more localities, spaced as much as $30 \mathrm{~km}$ apart. The 20 distinct eruptive events ( 1 tephra fall, 19 flows) over the four localities were summarized into three main compositional groups (A, B and C), based on major and trace element concentrations, as well as macroscopic and microscopic data. Flow unit boundaries are difficult to recognize in the compacted facies, whereas less compacted facies boundaries near the top of a cooling unit are more easily identifiable. In the compacted facies, flow unit boundaries often consist of eroded 10 cm-thick discontinuities. In contrast, less compacted facies boundaries are sharp and can occur over a $<2$-cm-interval. Weathering color and volcanic textures usually enhance the contrasts between flow units. For

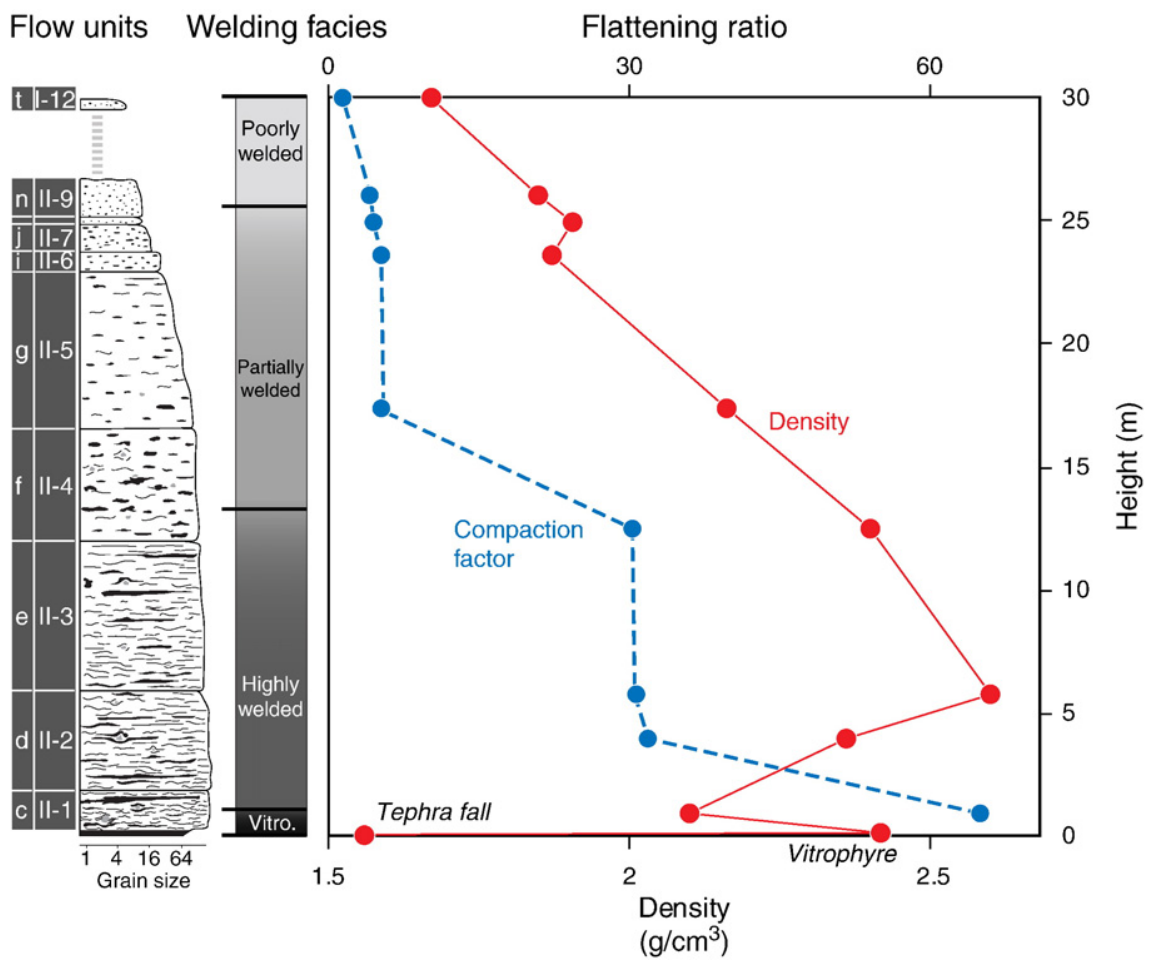

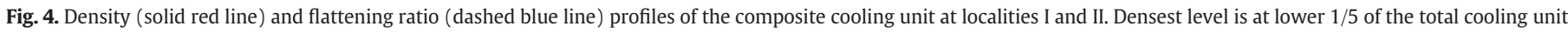

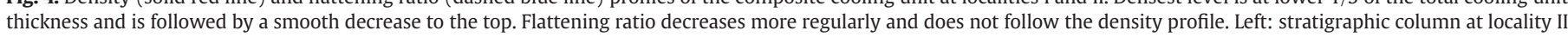

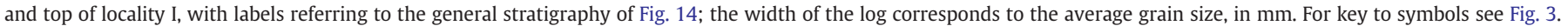


a few units (e.g. I-5, III-3), we do not know whether they represent source-controlled or emplacement-controlled flow units. The latter are interpreted to have formed during transport and not directly related to vent processes. The very thin units at the top of AY - as in many other ignimbrites on Gran Canaria - are mostly emplacement-controlled. Several flow units grouped into the same welding facies, are characterized by similar structures and textures, most of which are the result of compaction, welding and devitrification.

Highly welded and flattened AY fiamme consist mainly of microcrystalline alkali feldspars, aegirine and zeolites, which were probably formed during devitrification and post-emplacement vaporphase crystallization (Fig. 3). A significant amount of the deposit (18 vol.\%) consists of large fiamme in the lower flow units, but they disappear rapidly upwards. In proximal deposits, fiamme concentration decreases upward from 60 to 15 vol.\%, contrasting with medial deposits where their concentration fluctuates from only 45 to 25 vol.\% (Fig. 5 and Electronic Suppl.).

AY shows variations in its phenocrysts content. Feldspar abundance increases rapidly in the bulk rock through two-thirds of the section, and is then followed by a steady decrease, especially in proximal localities (Fig. 5). Clinopyroxene abundance decreases up section in proximal deposits, whereas medial deposit patterns are less consistent (i.e. locality III; Fig. 6). Titanite and haüyne phenocrysts strongly decrease in abundance upward at every locality.

Large (>60 mm diameter) lithoclasts reach 10 vol.\% in proximal deposits, but rapidly disappear in the upper flow units. Overall, lithoclast abundance progressively decreases upward from $18 \%$ to less than $5 \%$ at all localities (Fig. 5 and Electronic Suppl.). Lithoclasts (mm to $\mathrm{dm}$ in size) are dominantly altered dark phonolite lava fragments, with minor ignimbrites and fine-grained undifferentiated clasts. Rare meter-sized clasts are either compacted tuff or large phonolite lava clasts; cognate subvolcanic rocks are virtually absent.

The matrix is strongly welded and entirely recrystallized and the formerly glassy shards now consist entirely of microcrystalline alkali feldspar, aegirine and locally also of zeolites. The grain size and fibrous habitus of these crystals clearly indicate they are not intratelluric. Matrix amount increases upward from 25 to 75 vol.\% in proximal, and from 30 to 55 vol.\% in medial deposits (Fig. 5, Electronic Suppl.).

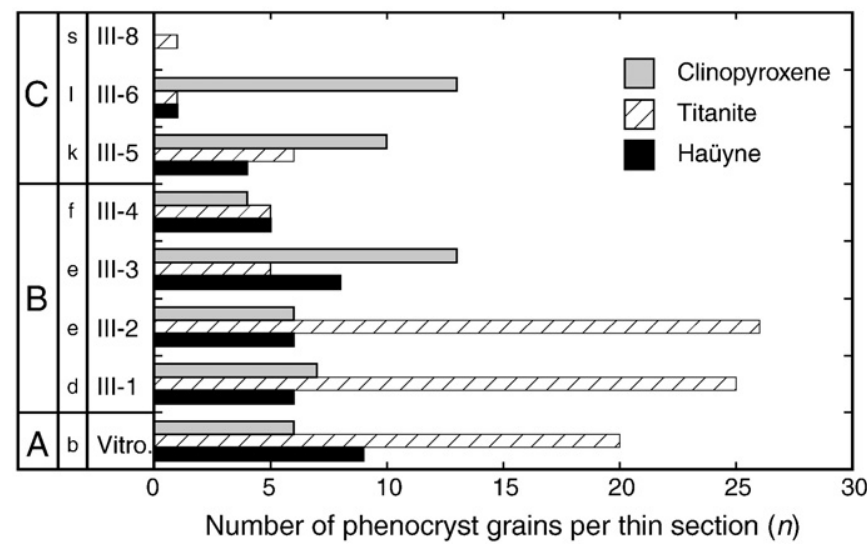

Fig. 6. Accessory phenocryst occurrence in medial locality III Titanite and haüyne decrease in abundance up section. Left: letters and numbers refer to the general stratigraphy of Fig. 14.

\section{Petrography and mineralogy}

Phenocrysts in AY are dominantly alkali feldspar with minor biotite, clinopyroxene, Fe-Ti oxides, titanite, haüyne and apatite. Homogeneous, tabular, Carlsbad-twinned alkali feldspars (anorthoclase and sanidine), represent more than $95 \%$ of the phenocrysts (Fig. 5, Electronic Suppl.) and range from 7 to 18\%. Their size varies from $<0.1$ to $2 \mathrm{~mm}$ in diameter when broken, to $1-3 \mathrm{~mm}$ (rarely 10 ) when unbroken. Most phenocrysts are broken (Fig. 7) and show subhedral, equant or triangular shapes (see Allen and McPhie, 2003). Feldspar fragments are preferentially concentrated in the matrix, whereas the fiamme contain fewer and mainly unbroken euhedral crystals. Crystal elongation, as well as perpendicular cleavage, favored subhedral chunk fragmentation (Fig. 3). Dark, pleochroic and commonly euhedral $<0.5$ to $4 \mathrm{~mm}$ biotite is the second most common phenocryst phase, but never reaches 1 vol.\%. Biotite sometimes occurs as inclusions in alkali feldspar. Euhedral green clinopyroxene phenocrysts $(2-3 \mathrm{~mm})$ commonly have a slight dark yellow

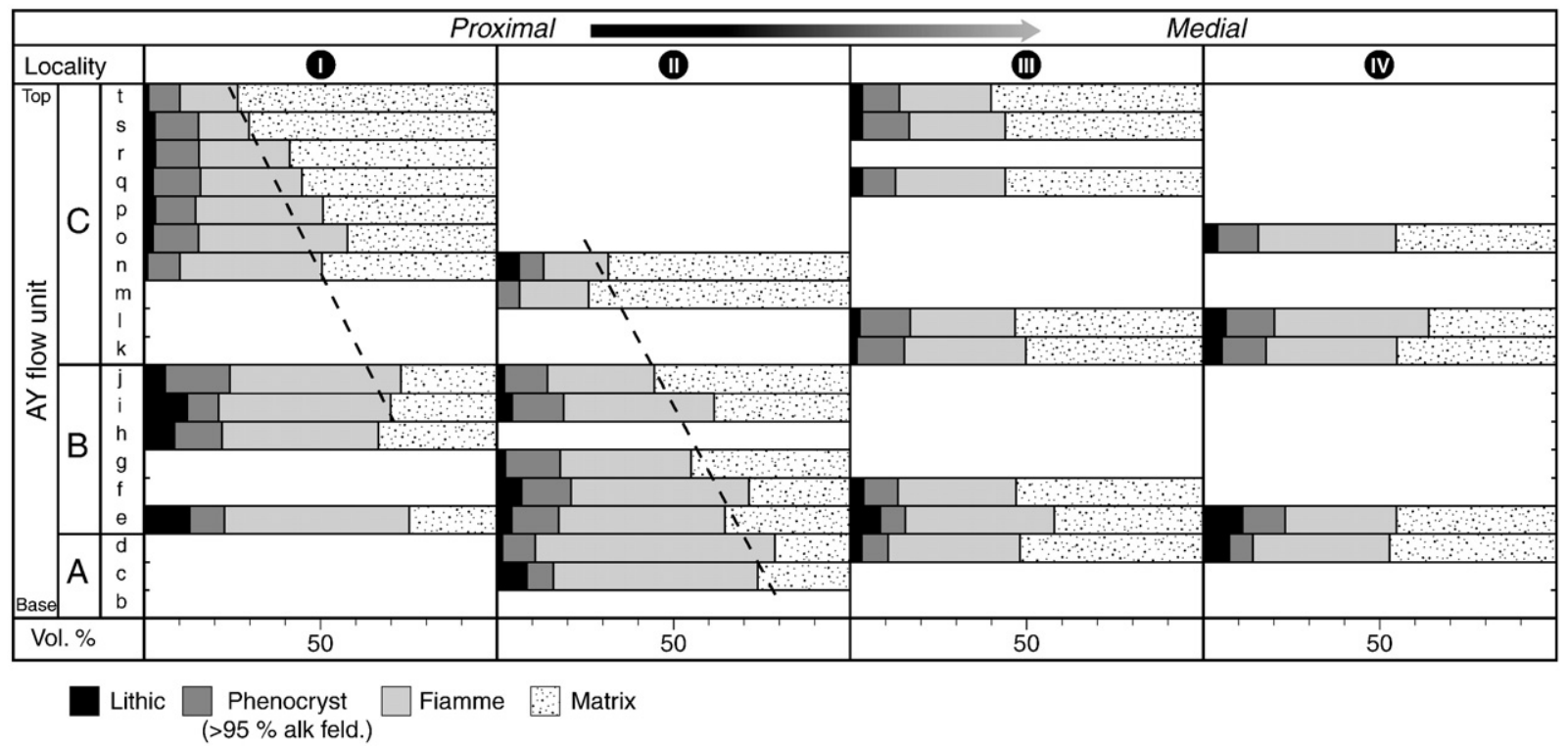

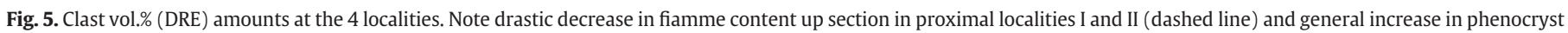
content up to flow unit $i$. Flow unit $a$ was too poorly preserved for modal analysis. Left: letters refer to general stratigraphy of Fig. 14 . 

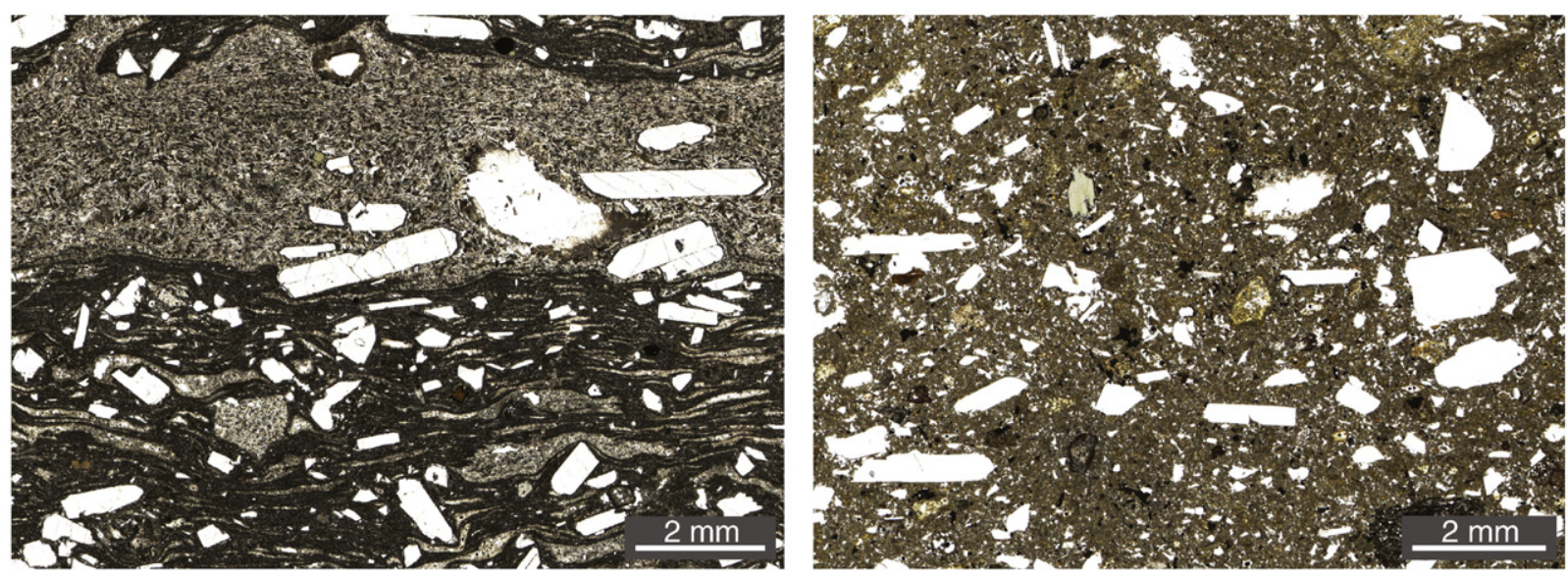

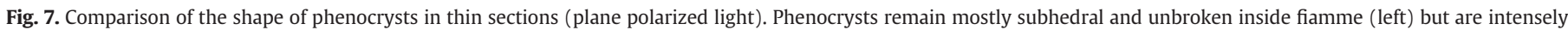
fragmented in the matrix. The highly welded facies (left) shows less fragmented phenocrysts than the poorly welded (right).

pleochroism. Most clinopyroxene crystals are intergrown with Fe-Ti oxides or occur as inclusions in alkali feldspar. Titanite phenocrysts $(0.5 \mathrm{~mm})$, usually diamond-shaped are rare. Most occur as inclusions in alkali feldspar, clinopyroxene and biotite. Although most haüyne (micro)phenocrysts ( 0.2 to $0.5 \mathrm{~mm}$ ) are altered, they are identified by their euhedral hexagonal shape. Most apatite microphenocrysts occur as small inclusions (less than $0.2 \mathrm{~mm}$ in length) in alkali feldspar or clinopyroxene.

\section{Geochemistry}

\subsection{Bulk rock compositions}

Bulk rock analyses for major and trace elements were carried out for each flow unit from all four localities. All rocks are trachytes in the conventional TAS diagram (Le Bas et al., 1986). $\mathrm{SiO}_{2}$ concentrations range from 61 to 63.5 wt.\%, with $\mathrm{Na}_{2} \mathrm{O}+\mathrm{K}_{2} \mathrm{O} 11-13$ wt.\%. $\mathrm{MgO}$ and $\mathrm{CaO}$ concentrations are $<1$ wt.\% each. $\mathrm{Al}_{2} \mathrm{O}_{3}$ ranges from $17-19$ wt.\%, while $\mathrm{Fe}_{2} \mathrm{O}_{3}^{*}$ ranges between 3.5 and 5 wt.\% (Fig. 8a and Table 1). Bulk rock compositions of AY are at the border of peralkaline compositions, with an agpaicity index [A.I. $=\mathrm{mol}(\mathrm{Na}+\mathrm{K}) / \mathrm{Al}]$ close to 1 that increases up section. Comparison between bulk rock and fiamme shows that bulk rock samples were lithic-free and consist entirely of juvenile components (Fig. 8b).

The REE patterns (Fig. 9, Table 1 and Electronic Suppl.) are parallel and decrease rather smoothly by almost two orders of magnitudes from light (LREE) to heavy rare earth elements (HREE). The REE pattern of AY is similar to trachytic/phonolitic lava flows on Tenerife (Wolff and Storey, 1984; Ablay et al., 1995, 1998; Wolff et al., 2000; Bryan, 2006) contrasting with the more depleted MREE of the Mogán Group ignimbrites (Freundt and Schmincke, 1995b; Kobberger and Schmincke, 1999; Troll and Schmincke, 2002) (Fig. 9).

\subsubsection{Variations in the stratigraphy}

Most of the major elements decrease in concentration upward in the stratigraphy, whereas $\mathrm{SiO}_{2}$ (and $\mathrm{K}_{2} \mathrm{O}$ ) show an increase (Fig. 10). Overall, the concentration of $\mathrm{Fe}_{2} \mathrm{O}_{3}^{*}$ shows a regular decrease. The enrichment factor (most evolved/less evolved concentration) of bulk rock major elements broadly follows the stratigraphy and remains low to very low ( 1.0 for $\mathrm{SiO}_{2}, 1.3$ for $\mathrm{Fe}_{2} \mathrm{O}_{3}^{*}, 1.2$ for $\mathrm{CaO}, 1.25$ for $\mathrm{TiO}_{2}$ ). However, the concentration of many trace elements shows a strongly different behavior, with a pronounced decrease (enrichment factor of 2) upward in the stratigraphy, except for Ba [0.3 for $\mathrm{Ba}, 1.8$ for $\mathrm{Zr}$ and $\sim 2$ for REE (Figs. 10, 11, Table 1 and Electronic Suppl.). The REE and (a)

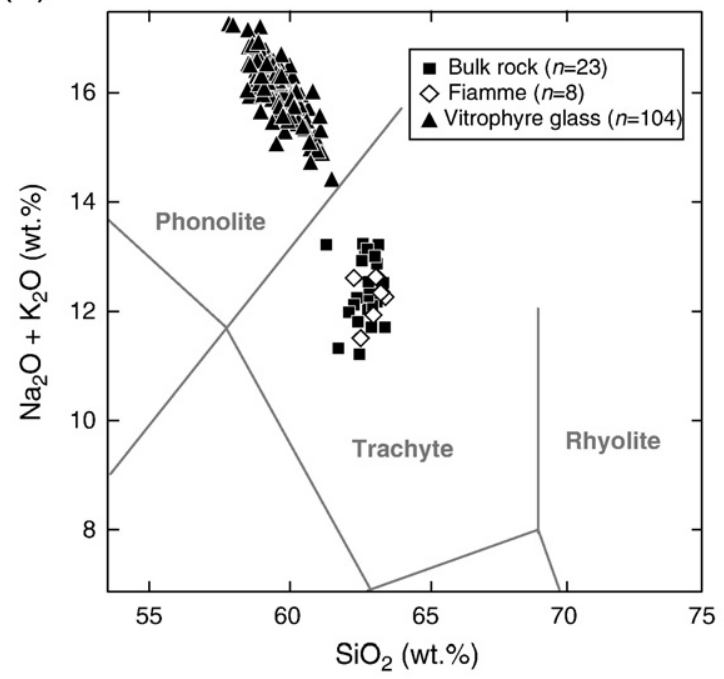

(b)

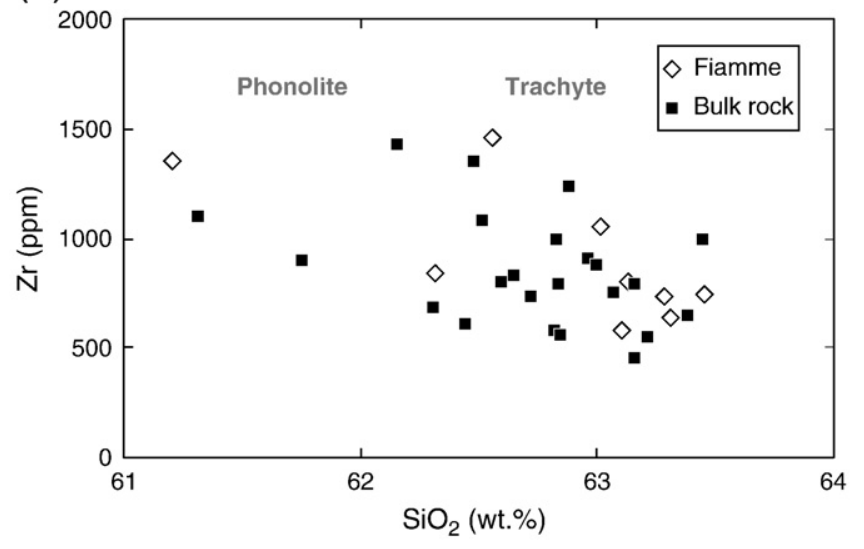

Fig. 8. a: TAS diagram of bulk rock, fiamme and glass analyses of the 4 sampled localities. Bulk rock and fiamme stay in the trachytic compositional field. Glass is exclusively phonolitic in composition. $\mathrm{n}=$ number of analyses. Compositional boundaries after Le Bas et al. (1986); b: Fiamme and bulk rock composition plot demonstrates magma homogeneity and absence of contamination by lithoclasts in the samples analyzed. 
Table 1

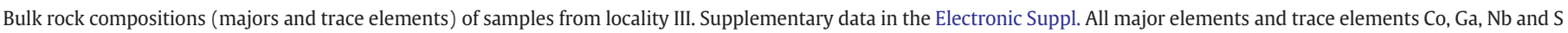

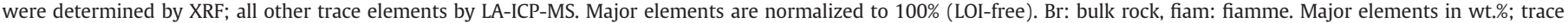
elements in ppm.

\begin{tabular}{|c|c|c|c|c|c|c|c|c|c|c|}
\hline & III-vitro & III-1 & III-2 & III-3 & III-4 & III-5 & III-6 & III-7 & III-8 & III-9 \\
\hline XRF & $b r$ & $b r$ & $b r$ & fiam & $b r$ & $b r$ & $b r$ & $b r$ & $b r$ & $b r$ \\
\hline $\mathrm{SiO}_{2}$ & 61.32 & 62.17 & 62.15 & 62.56 & 62.47 & 62.83 & 63.16 & 63.00 & 62.84 & 62.44 \\
\hline $\mathrm{TiO}_{2}$ & 0.93 & 0.96 & 0.95 & 0.97 & 0.94 & 0.94 & 0.87 & 0.88 & 0.91 & 0.91 \\
\hline $\mathrm{Al}_{2} \mathrm{O}_{3}$ & 17.89 & 18.68 & 17.93 & 18.02 & 17.97 & 17.85 & 17.98 & 18.46 & 18.62 & 18.90 \\
\hline $\mathrm{Fe}_{2} \mathrm{O}_{3}^{*}$ & 4.70 & 4.87 & 4.68 & 4.71 & 4.57 & 4.16 & 3.88 & 3.92 & 3.98 & 4.10 \\
\hline $\mathrm{MnO}$ & 0.43 & 0.42 & 0.40 & 0.40 & 0.37 & 0.33 & 0.30 & 0.36 & 0.26 & 0.27 \\
\hline MgO & 0.63 & 1.02 & 0.82 & 0.94 & 0.89 & 0.95 & 0.88 & 0.71 & 0.60 & 0.65 \\
\hline $\mathrm{CaO}$ & 0.81 & 0.73 & 1.07 & 0.84 & 0.97 & 0.87 & 0.71 & 0.53 & 0.49 & 0.45 \\
\hline $\mathrm{Na}_{2} \mathrm{O}$ & 8.01 & 4.63 & 6.23 & 6.05 & 6.15 & 6.34 & 6.26 & 5.97 & 5.36 & 4.14 \\
\hline $\mathrm{K}_{2} \mathrm{O}$ & 5.20 & 6.48 & 5.73 & 5.47 & 5.64 & 5.70 & 5.90 & 6.12 & 6.90 & 8.10 \\
\hline $\mathrm{P}_{2} \mathrm{O}_{5}$ & 0.08 & 0.04 & 0.02 & 0.04 & 0.03 & 0.03 & 0.05 & 0.05 & 0.04 & 0.03 \\
\hline LOI & 5.08 & 5.87 & 3.74 & 3.77 & 3.91 & 3.49 & 1.07 & 2.84 & 3.02 & 3.11 \\
\hline Total & 99.45 & 99.33 & 99.61 & 99.12 & 99.45 & 99.00 & 99.51 & 100.03 & 99.43 & 99.68 \\
\hline \multicolumn{11}{|c|}{$L A-I C P-M S$} \\
\hline$n$ & 2 & 2 & 2 & 2 & 2 & 2 & 2 & 2 & 2 & 2 \\
\hline $\mathrm{Ba}$ & 26.5 & 32.8 & 44.5 & 43.5 & 46.3 & 43.6 & 61.5 & 117.9 & 100.3 & 94.2 \\
\hline $\mathrm{Rb}$ & 103.5 & 140.0 & 122.8 & 125.8 & 111.2 & 96.4 & 99.4 & 113.5 & 141.0 & 169.7 \\
\hline $\mathrm{Sr}$ & 45.0 & 42.0 & 289.0 & 138.0 & 34.0 & 29.0 & 17.0 & 25.0 & 16.0 & 16.0 \\
\hline $\mathrm{Y}$ & 80.0 & 93.0 & 95.6 & 96.0 & 110.8 & 70.8 & 68.9 & 94.6 & 64.8 & 40.5 \\
\hline $\mathrm{Zr}$ & 1100.0 & 1406.7 & 1430.2 & 1457.9 & 1353.6 & 993.5 & 788.0 & 877.0 & 794.1 & 610.9 \\
\hline $\mathrm{Nb}$ & 310.0 & 338.8 & 343.7 & 345.5 & 318.8 & 245.2 & 207.6 & 240.0 & 218.7 & 186.1 \\
\hline Th & 18.7 & 20.5 & 23.2 & 23.9 & 22.6 & 17.6 & 12.8 & 17.5 & 19.0 & 12.1 \\
\hline $\mathrm{U}$ & 4.3 & 2.0 & 2.3 & 1.3 & 2.0 & 1.7 & 1.0 & 1.8 & 2.3 & 2.4 \\
\hline $\mathrm{Pb}$ & 11.2 & 11.7 & 12.0 & 11.7 & 9.6 & 8.4 & 7.2 & 8.2 & 7.6 & 5.9 \\
\hline $\mathrm{Ga}$ & 34.0 & 38.0 & 32.0 & 35.0 & 32.0 & 30.0 & 28.0 & 29.0 & 29.0 & 34.0 \\
\hline $\mathrm{Zn}$ & 206.5 & 219.7 & 213.0 & 187.0 & 173.5 & 141.2 & 153.4 & 166.1 & 140.0 & 120.1 \\
\hline V & 33.8 & 38.0 & 41.6 & 37.3 & 39.2 & 33.6 & 33.5 & 40.4 & 40.1 & 35.6 \\
\hline $\mathrm{Hf}$ & 22.4 & 29.1 & 29.5 & 30.5 & 27.0 & 22.6 & 17.1 & 17.7 & 17.4 & 13.3 \\
\hline Cs & 1.4 & 1.2 & 0.8 & 1.2 & 0.7 & 0.4 & 0.7 & 0.1 & 0.2 & 0.1 \\
\hline Ta & 22.5 & 23.6 & 24.4 & 24.7 & 23.2 & 19.5 & 16.6 & 19.7 & 15.9 & 12.6 \\
\hline $\mathrm{La}$ & 174.5 & 192.2 & 211.9 & 211.9 & 197.6 & 168.1 & 142.2 & 232.5 & 164.3 & 113.3 \\
\hline $\mathrm{Ce}$ & 327.0 & 350.3 & 369.6 & 359.8 & 341.9 & 288.3 & 253.5 & 349.8 & 238.3 & 233.8 \\
\hline $\operatorname{Pr}$ & 34.6 & 36.6 & 41.4 & 38.8 & 38.0 & 34.5 & 29.8 & 51.0 & 34.2 & 24.8 \\
\hline $\mathrm{Nd}$ & 123.5 & 139.6 & 148.9 & 145.8 & 155.4 & 129.7 & 116.5 & 192.6 & 126.4 & 91.9 \\
\hline $\mathrm{Sm}$ & 19.2 & 23.1 & 26.1 & 24.2 & 24.8 & 20.0 & 18.1 & 30.6 & 21.5 & 13.7 \\
\hline $\mathrm{Eu}$ & 4.2 & 5.5 & 4.8 & 5.0 & 4.9 & 4.4 & 3.9 & 7.2 & 4.1 & 3.5 \\
\hline $\mathrm{Gd}$ & 14.7 & 21.5 & 20.1 & 20.9 & 23.1 & 17.8 & 17.5 & 25.8 & 14.5 & 9.8 \\
\hline $\mathrm{Tb}$ & 2.2 & 2.7 & 3.3 & 3.2 & 3.1 & 2.5 & 1.9 & 3.1 & 2.2 & 1.4 \\
\hline Dy & 14.2 & 20.0 & 17.2 & 20.4 & 19.4 & 14.4 & 13.7 & 19.0 & 12.9 & 9.2 \\
\hline Ho & 2.8 & 3.5 & 3.4 & 3.7 & 4.0 & 2.7 & 2.4 & 3.4 & 2.3 & 1.5 \\
\hline $\mathrm{Er}$ & 7.0 & 9.4 & 9.8 & 10.6 & 10.1 & 7.7 & 6.6 & 9.1 & 6.5 & 4.8 \\
\hline $\mathrm{Tm}$ & 1.4 & 1.0 & 1.2 & 1.3 & 1.6 & 0.8 & 1.1 & 1.2 & 0.9 & 0.6 \\
\hline $\mathrm{Yb}$ & 6.8 & 7.8 & 7.4 & 9.5 & 7.8 & 6.4 & 5.6 & 7.8 & 5.6 & 3.5 \\
\hline $\mathrm{Lu}$ & 1.1 & 1.3 & 1.2 & 1.2 & 1.3 & 0.9 & 0.7 & 1.2 & 0.8 & 0.6 \\
\hline
\end{tabular}

other immobile elements such $\mathrm{Nb}$, Ta and $\mathrm{Zr}$ show nice parallelism in their decreasing concentrations at locality III, which emphasizes the boundaries of compositional groups A, B and C (Fig. 11). In every locality, $\mathrm{Sr}$ has a positive peak anomaly (factor 4 to 10) about 5-7 m from the basal layer (Table 1 and Electronic Suppl.).

\subsection{Crystal and glass compositions}

Electron-microprobe (EMP) and LA-ICP-MS analyses were done on fresh glass, alkali feldspar, biotite, clinopyroxene and titanite phenocrysts (Fig. 12, Table 2 and Electronic Suppl.). Analyses were done on every flow unit at locality II, whereas only targeted flow units were analyzed at the three other localities; glass was only found in the vitrophyre facies. Generally, at least 6 feldspar and 3 biotite crystals were analyzed per flow unit and both cores and rims were analyzed where possible. Analyzed crystals came from several fiamme, as well as from the matrix. Thus, the plotted average compositions reflect crystal compositions of the entire flow unit. Comparisons between phenocryst cores and rims, as well as multiple analyses across several phenocrysts show homogeneous compositions in each grain (Fig. 12).

\subsubsection{Glass}

Vitrophyre glasses are phonolitic in composition with a high concentration (14-17 wt.\%) in alkalis elements (Fig. 8a, Table 2 and Electronic Suppl.). $\mathrm{Na}_{2} \mathrm{O}$ concentrations ( $11 \mathrm{wt} . \%$ ) are extremely high (twice as much as in the bulk rock), while other major elements such as $\mathrm{SiO}_{2}$ (59-60 wt.\%), $\mathrm{Al}_{2} \mathrm{O}_{3}$ (17 wt.\%) and $\mathrm{K}_{2} \mathrm{O}$ (5.0-5.5 wt.\%) are lower compared to whole rock compositions (Table 2 and Electronic Suppl.). Sr shows the same peculiar behavior (but higher), previously described for the bulk rock.

We have calculated the A.I. and the newly proposed index FK/A $\left[=\mathrm{mol}(\mathrm{Fe}+\mathrm{K}) / \mathrm{Al}\right.$, with all the Fe calculated as $\left.\mathrm{Fe}^{2+}\right]$ by White et al. (2003) for peralkaline rocks, which avoids post-crystallization $\mathrm{Na}_{2} \mathrm{O}$ loss in glassy rocks. In contrast to the bulk rock, AY glass is definitely peralkaline with its A.I. of 1.33 (standard deviation of 0.05). Moreover, the $\mathrm{FK} / \mathrm{A}=0.68$ (std. deviation of 0.02 ) index of AY matches White et al. (2003) results, confirming the relative freshness of the glass.

Low temperature of devitrification of the glass and crystallization of secondary minerals occurred throughout the entire thickness of the cooling unit except in the vitrophyre. Nevertheless, we assume that concentrations of immobile elements, such as REE and $\mathrm{Zr}$, which 

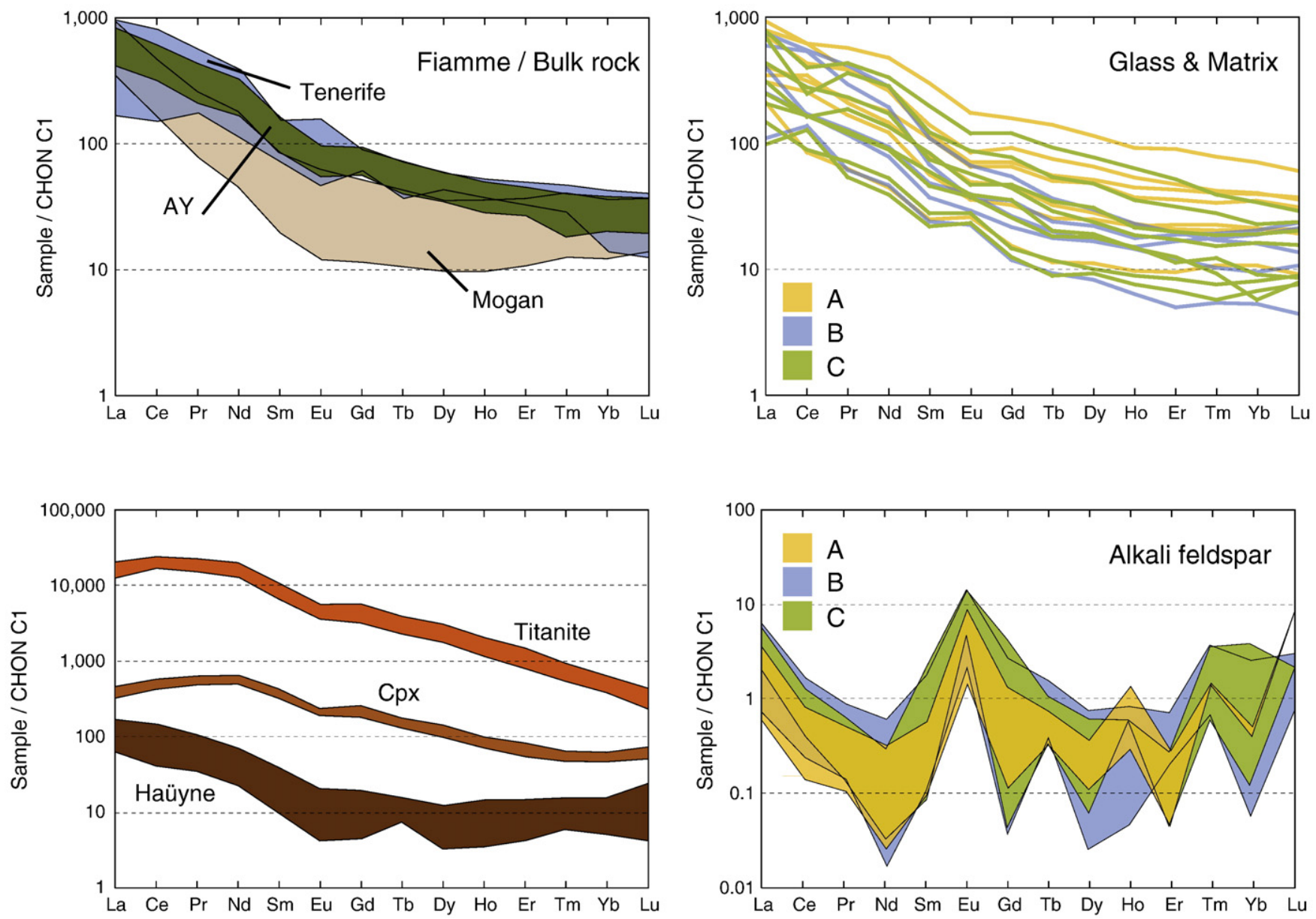

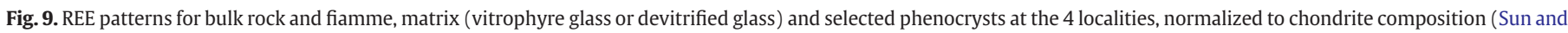

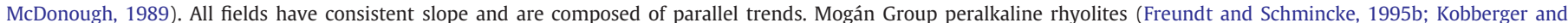

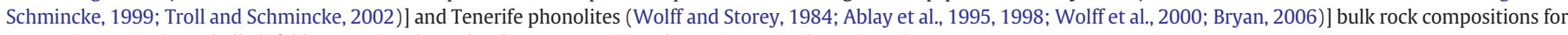
comparison. Matrix and alkali feldspar ratios show the three compositional groups A, B, C (see Fig. 14).

should not be substantially affected by secondary processes, did not change during devitrification. Most trace-element concentrations in the glass are higher than in the bulk rock: $\mathrm{Rb}$ and $\mathrm{Zr}$ are enriched by a factor of 2 in the matrix, REE and most other trace elements are enriched by about 1.3. Depletion is seen in $\mathrm{Sr}$ (factor 0.1 of bulk rock values), and $\mathrm{Ba}(0.25)$ and $\mathrm{V}(0.75)$ in their glass compositions (Tables 1, 2, Electronic Suppl.). REE patterns of each glass and matrix analysis at locality II are chiefly parallel and follow the slope of the bulk rock. This emphasizes the immobility of these elements in the devitrified matrix (Fig. 9).

\subsubsection{Alkali feldspar}

Alkali feldspar compositions range from sanidine to anorthoclase. In the ternary orthoclase (Or) - albite (Ab) - anorthoclase (An), their compositions lie in a field between $\mathrm{Or}_{30-40}-\mathrm{Ab}_{60-70}$ and below $\mathrm{An}_{03}$ [ 400 analyses on both crystal rims and cores (Fig. 12, Table 2 and Electronic Suppl.)]. $\mathrm{CaO}$ and $\mathrm{Na}_{2} \mathrm{O}$ concentrations increase up section (enrichment factor of 0.3 and 0.95 , respectively), whereas $\mathrm{K}_{2} \mathrm{O}$ and $\mathrm{Fe}_{2} \mathrm{O}_{3}^{*}$ decrease (enrichment factor of 1.25 and 1.1 , respectively). Consequently, Ab number increases with stratigraphy, whereas Or and An numbers decrease with the general characteristic of peralkaline fractionation trends (White et al., 2003).

Most trace element concentrations increase up section (enrichment factor of $\sim 2.5$ for Ce and $\mathrm{La}$ ), but remain at very low values. $\mathrm{Rb}$ decreases (factor 2.5) following the $\mathrm{K}_{2} \mathrm{O}$ trend. $\mathrm{Sr}$ and $\mathrm{Ba}$ seem to increase up section, but both cores and rims have a large range of concentrations (smaller than the detection limit to $12 \mathrm{ppm}$ and 10 to $600 \mathrm{ppm}$, respectively for the same flow units), although their concentration is much narrower in the vitrophyre facies and in the lower part of the highly welded facies. The REE patterns are chiefly parallel, showing an immobility of these elements in the alkali feldspars during post-depositional processes (Fig. 9 and Table 2 and Electronic Suppl.). The HREE in particular are very high for alkali feldspars. A strong positive anomaly in Eu is typical for the feldspar.

\subsubsection{Biotite}

Biotites have values of $\mathrm{Fe}_{25}^{2+} \mathrm{Mg}_{64} \mathrm{Ti}_{11}$ [based on the sum of cations; standard deviation $<1.5$ for 120 analyses on both crystal rim and core (Fig. 12, Table 2 and Electronic Suppl.)]. Some crystals are more enriched in $\mathrm{Fe}$ on their rims, possibly due to slight alteration/ oxidation, or to a wedge effect, when the underlying groundmass was partly analyzed with the crystal. Compositional trends are indistinct in major elements, except for an increase in $\mathrm{Al}_{2} \mathrm{O}_{3}$ and $\mathrm{TiO}_{2}$ upward in the stratigraphy (enrichment factor of 0.9 and 0.7 , respectively), and a decrease in $\mathrm{K}_{2} \mathrm{O}$ (factor of 1.2). Amongst trace elements, $\mathrm{V}$ shows a significant increase (factor of 0.6). No coherent trend in the stratigraphy is found with the REE. 

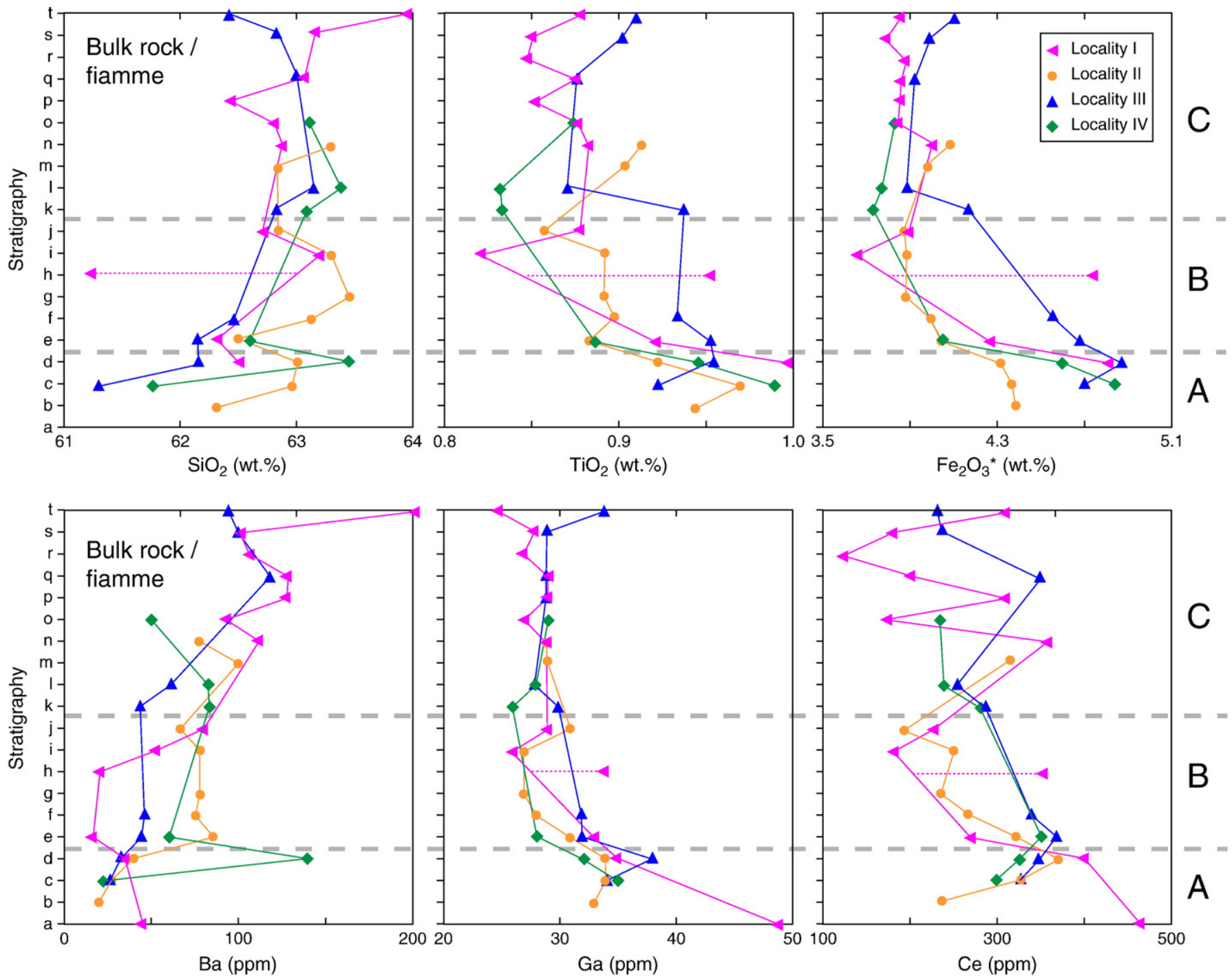

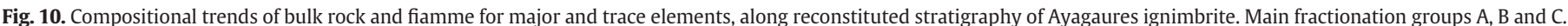
Compositional spike at flow unit h characterizes the behavior of a reversal, and is consequently not connected to the stratigraphy. Major elements not plotted for high LOI.

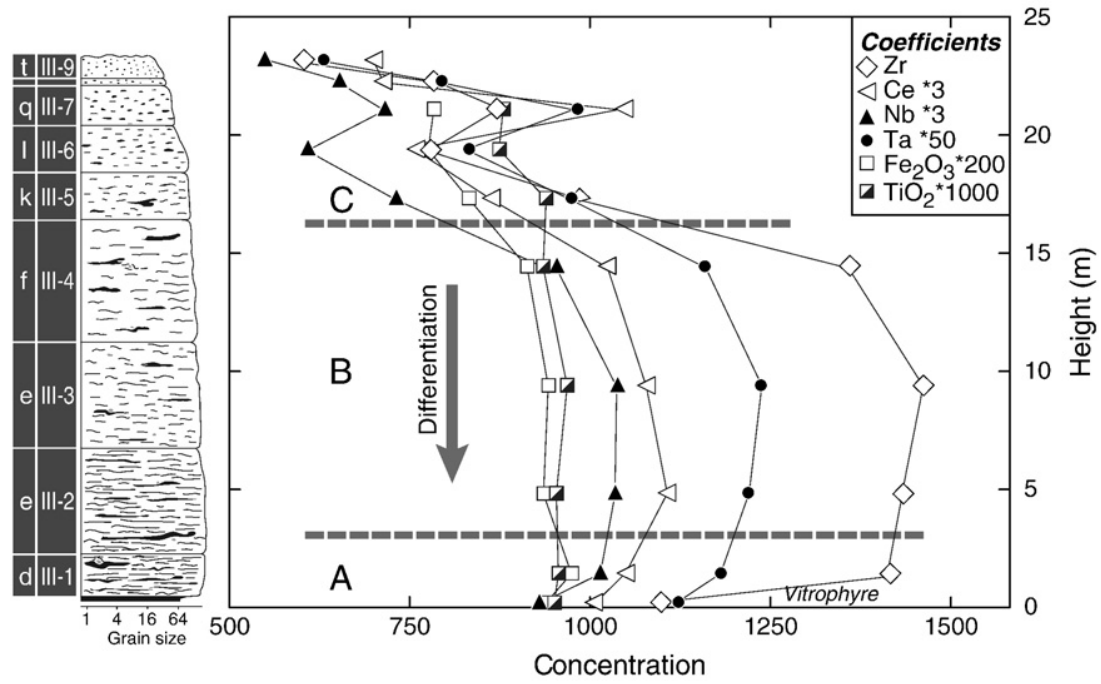

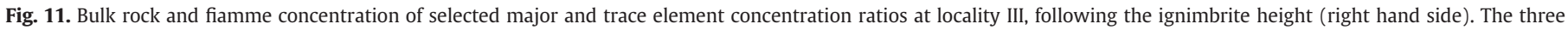

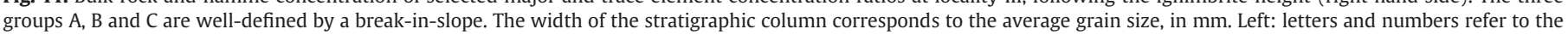
general stratigraphy of Fig. 14. For key to symbols see Fig. 3. 
(a)

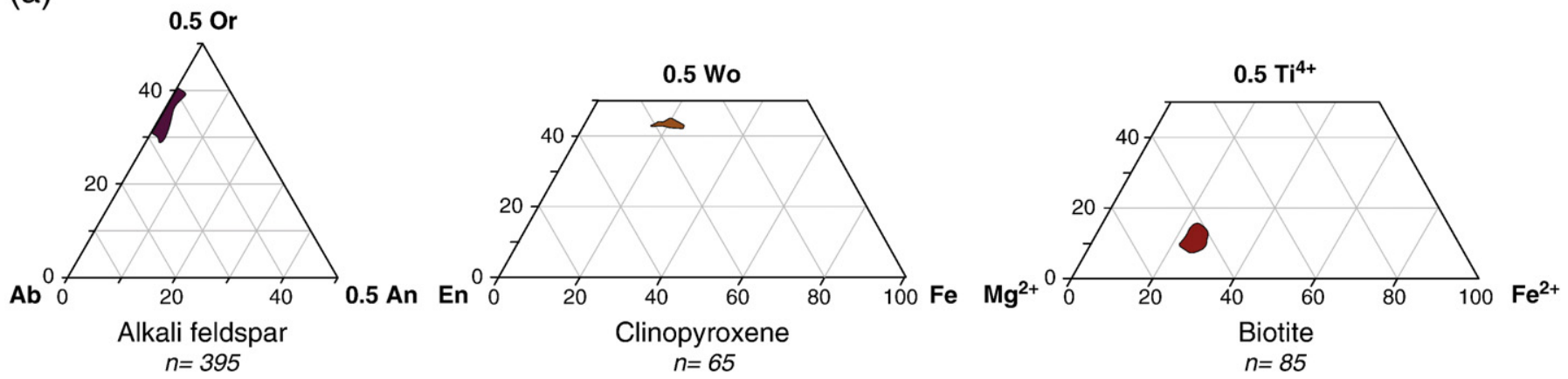

(b)
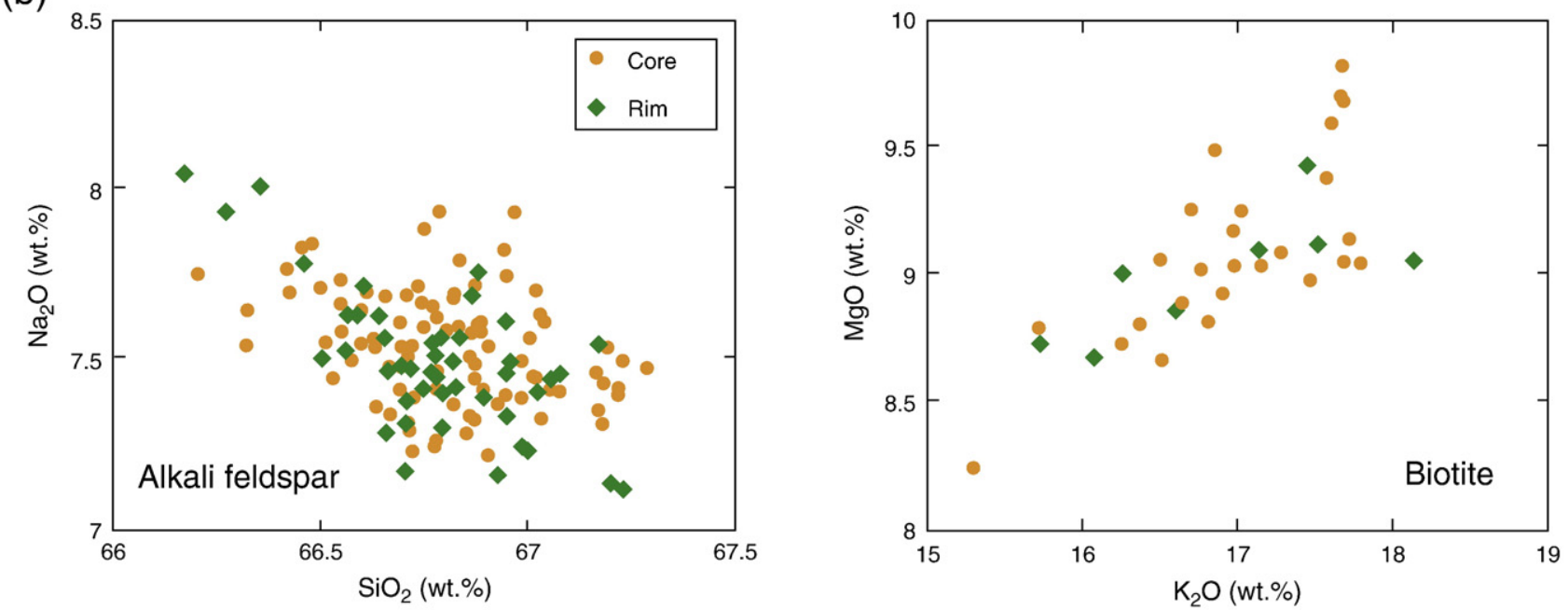

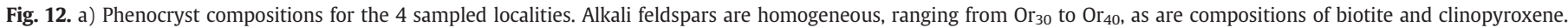
$\mathrm{n}=$ number of analyses; b) Core and rim compositions in feldspars and biotites at locality II indicate homogeneous, unzoned phenocrysts.

\subsubsection{Clinopyroxene}

Clinopyroxene phenocrysts are $\mathrm{En}_{37}, \mathrm{Fs}_{18.5}$ and $\mathrm{Wo}_{44.5}$ in composition [based on the sum of cations; standard deviation $<1$ within 60 analyses on both crystal rim and core (Fig. 12, Table 2 and Electronic Suppl.), and are named sodian-ferrian-augite following Morimoto et al. (1988). Absence of clinopyroxene in the uppermost flow units prevents accurate description of a compositional trend. Nevertheless, chemical trends show that concentrations of $\mathrm{SiO}_{2}$ and $\mathrm{Fe}_{2} \mathrm{O}_{3}^{*}$ are relatively homogeneous (Fig. 12a), but increase slightly upward in the stratigraphy, in contrast to $\mathrm{TiO}_{2}$ (Table 2 and Electronic Suppl.). Trace element concentrations are scattered, but REE compositions show a noticeable parallel pattern, indicating an immobile behavior as in the other crystals (Fig. 9, Table 2 and Electronic Suppl.).

\subsubsection{Other crystals}

Titanite compositions show a general decrease in $\mathrm{TiO}_{2}$, REE and other elements up section, except at locality I, where a reverse trend is seen (Table 2, Electronic Suppl.). The REE pattern is distinctly parallel and very narrow, reflecting a pronounced immobility of these elements during post-depositional processes (Fig. 9, Table 2 and Electronic Suppl.). Haüyne is rarely preserved due to alteration, but its REE pattern also shows an immobile behavior in these elements (Fig. 9, Table 2 and Electronic Suppl.). Fe-Ti oxides were all exsolved and were consequently not analyzed.

\section{Discussion}

Sequential evacuation of compositionally distinct bodies of magma has been inferred for many ignimbrites of the Mogán Group (e.g.
Schmincke, 1969; Freundt and Schmincke, 1995b; Kobberger and Schmincke, 1999; Troll and Schmincke, 2002). Freundt and Schmincke (1995b) described stratigraphic sub-units within 3 "structural" or "lithological" units in ignimbrite P1, zoned from rhyolite to basalt. Troll and Schmincke (2002) described 7 "flow units", based on matrix color as well as relative abundance of 3 types of rhyolitic and trachytic fiamme, but a specific fiamme and crystal composition per flow unit was not given. No data exist on the internal stratigraphy of ignimbrites in the Fataga Group.

\subsection{Flow unit correlation}

Reconstitution of source-controlled flow units was reviewed by Hildreth and Mahood (1985). They proposed field correlation, clast (fiamme, matrix, crystal and lithic fragments) proportional amounts, as well as clast geochemistry as main criteria to enable the reconstruction of the stratigraphy in space and time. Regional flow unit correlations of $\mathrm{AY}$ are based on, in decreasing order of importance: field characteristics, bulk rock and alkali feldspar compositions, relative clast abundance, biotite composition, presence of titanite and clinopyroxene composition (Figs. 5, 6, 8, 10, 12 and 13). The general stratigraphic correlation of the 4 sampled localities is presented (Figs. 10, 13 and 14). Only one flow unit, II-8, differed sufficiently from the others to be discriminated in the field, but had, unfortunately, no equivalent at other localities. Fiamme (or bulk rock) and crystal compositions determined by XRF and EMP of localities I, II, III and IV were used for flow unit correlations. Crystal at locality I were only analyzed for the most characteristic units. Major element concentrations of altered rocks were not plotted. The main 
discriminating elements used are $\mathrm{SiO}_{2}, \mathrm{Al}_{2} \mathrm{O}_{3}, \mathrm{Fe}_{2} \mathrm{O}_{3}^{*}, \mathrm{Ce}, \mathrm{Ga}, \mathrm{Nb}$ and $\mathrm{Zr}$ for bulk rocks; $\mathrm{SiO}_{2}, \mathrm{Al}_{2} \mathrm{O}_{3}, \mathrm{CaO}, \mathrm{Na}_{2} \mathrm{O}, \mathrm{K}_{2} \mathrm{O}, \mathrm{Rb}$ and $\mathrm{Ce}$ for alkali feldspars; $\mathrm{SiO}_{2}, \mathrm{Al}_{2} \mathrm{O}_{3}, \mathrm{TiO}_{2}, \mathrm{~V}$ and $\mathrm{Zn}$ for biotite.

\subsection{Magma chamber zonation}

\subsubsection{Compositional zoning}

Fractional crystallization is clearly the principal differentiation process generating compositional zoning during magma accumulation and crystallization in a shallow magma body (Smith, 1960, 1979; Hildreth, 1981, 1983; Hildreth and Mahood, 1985; Hildreth and Wilson, 2007). Bulk rock behavior show that AY follows the general model of large silicic differentiated magma chambers, with a progressive tapping of its compositionally zoned magma reservoir from layer $a$ (highly evolved) to layer $t$ (less evolved). Nevertheless, differentiation in highly alkaline bodies seems to behave differently than in silicic ones. A cryptic zoning is observed by the strong variations in trace element concentration - especially Ba (Wolff and Storey, 1984) - whereas most major elements are less affected (Fig. 10). This contrasts with silicic systems, in which both major and trace elements characterize the fractionation.

Although major element concentrations in the AY follow a specific increasing or decreasing trend upward in the stratigraphy, they range narrowly in composition with the notable exception of $\mathrm{CaO}$ for alkali feldspars. In contrast, trace element concentrations vary more significantly and follow typical peralkaline fractionation trends (White et al., 2003). Caution should be exercised in interpreting $\mathrm{Sr}$ and $\mathrm{Ba}$ trends for bulk rock and mineral composition due to their mobility during alteration. Nevertheless, Ba broadly increases with stratigraphy, confirming a correlated elevation of magma temperature, pressure and $\mathrm{H}_{2} \mathrm{O} \%$ (Guo and Green, 1989).

\subsubsection{Compositional groups}

The stratigraphic composition of AY is generally most highly evolved at the base of the stratigraphy, which represents the first magma erupted, and corresponds to the general downward tapping model of a compositionally zoned magma reservoir. The main crystals to fractionate were alkali feldspars (group B) and high-REE crystals such as titanite with possibly allanite and/or chevkinite (group A; Troll et al., 2003). The groups A, B and C show similar geochemical concentrations or similar behavior in their compositional variations (Figs. 10, 13, 15 and Table 3).

The three compositional trends are most likely due to feldspar (group B) and titanite (group A) fractionation. Flow units 8 and 9 at locality III indicate the probable presence of reversals (see below) by their abnormal composition compared to the general fractionation trend (Fig. 13). Abnormal compositions compared to a zonation by fractional crystallization may also reflect contamination of the magma by external sources, such as adjacent magma batches or minor country-rock assimilation. However, the overall compositional zoning of AY suggests these effects to be minor.

The compositional groups $\mathrm{A}, \mathrm{B}$ and $\mathrm{C}$ are well defined with the variation of concentration in immobile elements, such as $\mathrm{REE}, \mathrm{Zr}, \mathrm{Nb}$, $\mathrm{TiO}_{2}$ and Ta (Fig. 11) or Ce (Fig. 15), plotted against the overall decrease of $\mathrm{Fe}_{2} \mathrm{O}_{3}^{*}$ or the thickness of the ignimbrite at locality III.

\subsubsection{Reversals}

Reversals are defined as compositional spikes and have compositions that deviate from the trends observed in the stratigraphy [e.g. flow units $h$ and $n$ (Fig. 10)]. Their abnormal position in the stratigraphy most likely reflects magma evacuation complexities (Wolff and Storey, 1984; Freundt and Schmincke, 1995a). Blake and Ivey (1986) and Freundt and Tait (1986) describe mechanisms to create magma mingling, implying ascent of low viscosity, hot less evolved magma through a more evolved (and more viscous) layer. Other scenarios related to the magma chamber structure and its modification during caldera collapse involving three-dimensional geometric complexities might also explain these abnormal erupted sequences.

\subsubsection{Example of correlation}

To document the method used throughout the entire stratigraphy, an example of correlation is here presented at the flow unit transition $c-d-e$, also corresponding to the transition between compositional groups $\mathrm{A}$ and $\mathrm{B}$.

Microscopic data show an increase in the abundance of alkali feldspar and lithoclasts between $d$ and $e$ (Fig. 5). But the main tool used to characterize the 3 flow units is the chemical composition (Figs. 10, 11 and 13). Bulk rock concentrations of $\mathrm{SiO}_{2}, \mathrm{TiO}_{2}$, Ga show high values in between $a$ to $d$, but show an overall decrease at the transition $d$ to $e$ (Fig. 10), whereas REE slightly increase (Fig. 11). Amongst phenocrysts, alkali feldspars concentrations remain more or less flat at this point, although biotites have a significant positive peak in $\mathrm{SiO}_{2}$ at $d$ (Fig. 13), comparable to its behavior in the bulk rock. Thus, using a wide range of data, the three widespread flow units $c-d-e$ could be correlated at most localities (Fig. 14).

The major transition of the group $B$ and $C$ is well documented with the REE and $\mathrm{Fe}_{2} \mathrm{O}_{3}^{*}$, which show a drop in their concentration in between the flow units $f$ and $k$ at locality III.

\subsubsection{Compositional group $A$}

Group A ( $a$ to $d$ ) is defined by low content of alkali feldspar (Fig. 5), and high to very high amounts of trace phenocrysts (Fig. 6). Compositionally, bulk rock $\mathrm{Zr}$ concentration jumps up, whereas REE and compatible elements have high values and increase slightly (Fig. 11); the high $\mathrm{TiO}_{2}$ concentration corresponds to abundant titanite crystals (Fig. 6). $\mathrm{SiO}_{2}$ is low and increases, whereas $\mathrm{Fe}_{2} \mathrm{O}_{3}^{*}$ remains constant (Fig. 10). Trace element concentrations are very low for alkali feldspar (Fig. 13), except for $\mathrm{Rb} ; \mathrm{Na}_{2} \mathrm{O}$ increases at the expense of $\mathrm{K}_{2} \mathrm{O}$. Biotite shows an increase in $\mathrm{Al}_{2} \mathrm{O}_{3}$, but decreases in $\mathrm{TiO}_{2}$ (except at locality IV), whereas $\mathrm{V}$ remains mostly unchanged. Layer $a$ (tephra fall) is highly evolved compared to other layers of this group and does not always follow the general compositional trends (e.g. with Ce concentration).

\subsubsection{Compositional group $B$}

Group B, layers $e$ to $j$, is characterized by the largest change in composition. Overall gradual increase in abundance of alkali feldspar crystals (Fig. 5) and overall decrease in trace phenocryst content (Fig. 6), summarizes the main trends of this dominant body of the cooling unit. Another characteristic is a large decrease in bulk rock REE and other compatible element concentrations (Figs. 10, 11). $\mathrm{Fe}_{2} \mathrm{O}_{3}^{*}$ in particular shows a rather regular increasing trend. Alkali feldspar compositions show an increase in $\mathrm{CaO}$ (and $\mathrm{Na}_{2} \mathrm{O}$ ), while their $\mathrm{Rb}$ ( and $\mathrm{K}_{2} \mathrm{O}$ and $\mathrm{Fe}_{2} \mathrm{O}_{3}^{*}$ ) decreases (Fig. 13, Table 2 and Electronic Suppl.). In biotite, concentrations of $\mathrm{TiO}_{2}$ (and $\mathrm{V}$ ) increases, while $\mathrm{K}_{2} \mathrm{O}, \mathrm{MgO}, \mathrm{MnO}, \mathrm{FeO}$ and $\mathrm{Zn}$ decrease (Fig. 13, Table 2 and Electronic Suppl.).

\subsubsection{Compositional group $C$}

Group C, layers $j$ to $t$, corresponds to the less evolved part of AY. Stable abundance of alkali feldspar crystals (Fig. 5), low amount or absence of trace phenocrysts (Fig. 6), as well as absence of a continuous fractionation trend characterize this less evolved section of the ignimbrite. Changes in bulk rock composition are generally small, and unchanging trends dominate. $\mathrm{Sr}$ and Ba are moderately abundant in the alkali feldspars, but range widely in concentration. $\mathrm{TiO}_{2}$ concentrations in biotite are generally high (Fig. 13). Local compositional peaks in bulk rock trace elements (such as with $\mathrm{Ce}$ ) most likely represent reversals (unit $m$ ) or country-rock contamination (Figs. 10 and 13). 
Table 2

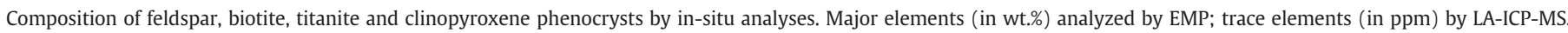
Supplementary data in the Electronic Suppl. Major elements are normalized to $100 \%$ (LOI free). $\mathrm{n}=$ number of analyses.

\begin{tabular}{|c|c|c|c|c|c|c|c|c|c|}
\hline \multirow[t]{2}{*}{ EMP } & \multirow{2}{*}{$\frac{\text { Glass }}{\text { II-vitro }}$} & \multicolumn{5}{|l|}{ Feldspar } & \multicolumn{3}{|l|}{ Titanite } \\
\hline & & III-vitro & III-1 & III-2 & III-4 & III-5 & III-6 & III-9 & III-1 \\
\hline$n$ & 37 & 20 & 13 & 7 & 11 & 16 & 8 & 12 & 3 \\
\hline $\mathrm{SiO}_{2}$ & 60.12 & 67.35 & 67.04 & 66.79 & 68.03 & 67.96 & 67.93 & 67.82 & 28.55 \\
\hline $\mathrm{TiO}_{2}$ & 0.93 & - & - & - & - & - & - & - & 36.84 \\
\hline $\mathrm{Al}_{2} \mathrm{O}_{3}$ & 17.13 & 18.52 & 18.67 & 18.39 & 18.43 & 18.66 & 18.78 & 18.69 & 0.48 \\
\hline $\mathrm{Cr}_{2} \mathrm{O}_{3}$ & 0.03 & & - & - & - & - & - & - & - \\
\hline $\mathrm{Fe}_{2} \mathrm{O}_{3}$ & - & 0.61 & 0.53 & 0.59 & 0.59 & 0.54 & 0.48 & 0.51 & 2.58 \\
\hline $\mathrm{FeO}^{*}$ & 3.91 & - & - & - & - & - & - & - & - \\
\hline $\mathrm{MnO}$ & 0.38 & - & - & - & - & - & - & - & 0.25 \\
\hline $\mathrm{MgO}$ & 0.44 & - & - & - & - & - & - & - & 0.02 \\
\hline $\mathrm{CaO}$ & 0.57 & 0.13 & 0.21 & 0.15 & 0.14 & 0.24 & 0.38 & 0.33 & 25.49 \\
\hline $\mathrm{Na}_{2} \mathrm{O}$ & 10.26 & 7.52 & 7.51 & 7.47 & 7.60 & 7.72 & 7.83 & 7.77 & 0.38 \\
\hline $\mathrm{K}_{2} \mathrm{O}$ & 5.35 & 6.45 & 6.26 & 6.40 & 6.45 & 6.22 & 5.93 & 6.07 & - \\
\hline $\mathrm{Cl}_{2} \mathrm{O}$ & 0.20 & - & - & - & - & - & - & - & - \\
\hline $\mathrm{P}_{2} \mathrm{O}_{5}$ & 0.04 & - & - & - & - & - & - & - & - \\
\hline $\mathrm{F}$ & 0.40 & - & - & - & - & - & - & - & - \\
\hline $\mathrm{H}_{2} \mathrm{O}$ & - & - & - & - & - & - & - & - & 1.07 \\
\hline $\mathrm{BaO}$ & 0.10 & - & - & - & - & - & - & - & - \\
\hline Total & 99.87 & 100.58 & 100.21 & 99.78 & 101.24 & 101.33 & 101.33 & 101.19 & 95.65 \\
\hline \multicolumn{10}{|c|}{$L A-I C P-M S$} \\
\hline$n$ & 3 & 3 & 6 & 5 & 4 & 5 & 7 & 5 & 1 \\
\hline Ba & 5.25 & 13.4 & 9.5 & 17.1 & 63.9 & 29.6 & 62.0 & 621.6 & 1.0 \\
\hline $\mathrm{Ce}$ & 378.84 & 0.5 & 0.7 & 0.7 & 1.2 & 1.0 & 1.3 & 2.3 & 12082.6 \\
\hline Cs & 1.61 & - & - & - & - & - & - & - & - \\
\hline Dy & 12.91 & - & - & - & - & - & - & - & 520.8 \\
\hline $\mathrm{Er}$ & 7.07 & - & - & - & - & - & - & 0.1 & 167.4 \\
\hline $\mathrm{Eu}$ & 4.11 & 0.4 & 0.3 & 0.6 & 0.6 & 0.6 & 0.7 & 1.2 & 228.9 \\
\hline Gd & 14.61 & - & - & - & - & 0.1 & 0.1 & 0.1 & 803.4 \\
\hline Hf & 24.01 & - & - & - & - & - & - & - & 190.0 \\
\hline Но & 2.50 & - & - & - & - & - & - & - & 78.0 \\
\hline $\mathrm{La}$ & 186.37 & 0.8 & 1.0 & 1.1 & 1.5 & 1.3 & 1.5 & 2.8 & 4269.3 \\
\hline $\mathrm{Lu}$ & 0.95 & - & - & - & - & - & - & - & 7.0 \\
\hline $\mathrm{Nb}$ & 374.91 & - & 0.2 & - & - & - & 0.1 & - & 5536.3 \\
\hline $\mathrm{Nd}$ & 122.70 & 0.1 & 0.1 & 0.2 & 0.2 & 0.1 & 0.2 & 0.3 & 6959.8 \\
\hline $\mathrm{Pb}$ & 15.54 & 1.0 & 0.9 & 1.0 & 0.9 & 0.9 & 1.1 & 1.1 & 0.8 \\
\hline $\operatorname{Pr}$ & 36.27 & - & 0.1 & - & 0.1 & - & 0.1 & 0.1 & 1681.2 \\
\hline $\mathrm{Rb}$ & 146.16 & 41.2 & 40.7 & 35.9 & 29.5 & 28.7 & 35.6 & 19.4 & 0.3 \\
\hline $\mathrm{Sc}$ & 3.56 & - & - & - & - & - & - & - & 10.3 \\
\hline $\mathrm{Sm}$ & 18.22 & - & 0.1 & - & - & - & - & 0.1 & 1179.4 \\
\hline $\mathrm{Sr}$ & 0.93 & 1.5 & 1.5 & 2.1 & 3.1 & 2.4 & 3.0 & 8.1 & 1.6 \\
\hline Та & 21.74 & - & - & - & - & - & - & - & 1048.9 \\
\hline $\mathrm{Tb}$ & 2.09 & - & - & - & - & - & - & - & 102.5 \\
\hline Th & 21.42 & - & - & - & - & - & - & - & 21.0 \\
\hline $\mathrm{Tm}$ & 1.03 & - & - & - & - & - & - & - & 16.3 \\
\hline $\mathrm{U}$ & 5.88 & - & - & - & - & - & - & - & 2.3 \\
\hline V & 21.17 & 0.1 & - & 0.2 & - & 0.2 & 0.1 & - & 131.7 \\
\hline Y & 69.53 & - & - & - & - & - & - & 0.1 & 1694.0 \\
\hline $\mathrm{Yb}$ & 6.66 & - & - & 0.1 & - & - & - & - & 78.7 \\
\hline $\mathrm{Zn}$ & 255.73 & 0.3 & 1.6 & 1.2 & 1.2 & 1.1 & 1.9 & 2.3 & 12.4 \\
\hline $\mathrm{Zr}$ & 1142.87 & - & 0.6 & 0.2 & - & 0.1 & - & 0.1 & 4332.1 \\
\hline
\end{tabular}

\subsection{Magma evolution}

Shape and sizes of magma chambers, as well as magma rheology, are thought to be the critical parameters governing the extent of magma mixing (Blake and Ivey, 1986; Freundt and Schmincke, 1995b). A shallow depth, disc-like magma chamber is here suggested by the erupted magma volume of $>50 \mathrm{~km}^{3}$, the caldera size $(20 \mathrm{~km}$ of diameter), the relative homogeneity of the trachytic magma and the compositional zoning throughout the cooling unit. The parallelism of the REE pattern reflects a probable unique magmatic source as well as immobility of these elements during devitrification and slight alteration.

Magma evolution of the 3 compositional groups A, B and C of AY is interpreted as follows (Fig. 16). The narrow range of crystal and bulk rock compositions of AY suggests incremental eruption of multiple batches that had become strongly homogenized by vigorous convection in the shallow level magma chamber, or from a homogeneous evolved magma batch (Fig. 16a). AY magma contains clinopyroxene, oxide and titanite from an early crystallization event. These euhedral phenocrysts lack disequilibrium textures and are commonly found as inclusions in later-crystallized alkali feldspars. Presence of a less evolved magma body beneath the AY magma is inferred from evidence of more mafic components in the ignimbrite P1 in the Mogán Group (Freundt and Schmincke, 1995b).

Following a period of intense mixing, convection intensity decreased and the magma body approached quasi steady-state (and thermodynamic) equilibrium. Slow cooling and/or loss of fluids triggered a major episode of alkali feldspar and biotite phenocryst crystallization, inducing compositional zoning of the entire erupted magma body (Fig. 16b). 


\begin{tabular}{|c|c|c|c|c|c|c|c|c|c|c|c|c|}
\hline \multicolumn{7}{|l|}{ Biotite } & \multicolumn{6}{|c|}{ Clinopyroxene } \\
\hline III-vitro & III-1 & III-2 & III-4 & III-5 & III-6 & III-9 & III-vitro & III-2 & III-4 & III-5 & III-6 & III-9 \\
\hline 4 & 4 & 2 & 6 & 2 & 3 & 3 & 13 & 4 & 2 & 4 & 3 & 4 \\
\hline 39.49 & 37.63 & 38.84 & 38.80 & 38.24 & 38.69 & 38.67 & 51.60 & 52.23 & 52.07 & 52.06 & 52.36 & 51.68 \\
\hline 4.98 & 4.32 & 4.42 & 5.62 & 6.02 & 6.00 & 6.13 & 0.80 & 0.66 & 0.82 & 0.87 & 0.77 & 1.03 \\
\hline 10.90 & 10.66 & 10.83 & 11.56 & 11.43 & 11.46 & 11.69 & 1.07 & 0.79 & 1.03 & 1.04 & 1.02 & 0.94 \\
\hline 0.03 & 0.03 & 0.02 & 0.01 & 0.02 & 0.02 & 0.01 & 0.01 & 0.02 & 0.01 & 0.02 & 0.01 & 0.02 \\
\hline- & - & - & - & - & - & - & 5.01 & 4.91 & 6.17 & 6.54 & 5.07 & 25.12 \\
\hline 12.37 & 10.92 & 14.08 & 12.06 & 11.57 & 11.33 & 11.40 & 4.26 & 4.81 & 4.37 & 4.21 & 4.61 & 2.43 \\
\hline 0.85 & 0.67 & 1.02 & 0.80 & 0.60 & 0.57 & 0.65 & 1.31 & 1.48 & 1.43 & 1.45 & 1.38 & 0.76 \\
\hline 17.38 & 16.99 & 16.21 & 16.82 & 16.53 & 16.81 & 16.53 & 12.54 & 12.27 & 11.91 & 11.72 & 12.43 & 2.15 \\
\hline- & - & - & - & - & - & - & 20.60 & 20.65 & 20.10 & 19.92 & 20.49 & 5.99 \\
\hline 0.98 & 1.57 & 0.81 & 0.88 & 0.87 & 0.85 & 1.01 & 1.74 & 1.81 & 2.21 & 2.36 & 1.92 & 10.36 \\
\hline 9.06 & 8.07 & 8.85 & 8.93 & 7.74 & 7.85 & 8.33 & - & - & - & - & - & - \\
\hline- & - & - & - & - & - & - & - & - & - & - & - & - \\
\hline- & - & - & - & - & - & - & - & - & - & - & - & - \\
\hline- & - & - & - & - & - & - & - & - & - & - & - & - \\
\hline 4.07 & 3.88 & 4.00 & 4.06 & 3.99 & 4.02 & 4.04 & - & - & - & - & - & - \\
\hline- & - & - & - & - & - & - & - & - & - & - & - & - \\
\hline 100.12 & 94.74 & 99.07 & 99.54 & 96.99 & 97.61 & 98.46 & 98.95 & 99.63 & 100.08 & 100.19 & 100.04 & 100.47 \\
\hline 4 & 2 & 3 & 3 & 2 & 3 & 2 & 1 & 2 & 2 & 3 & 3 & - \\
\hline 3.7 & 3.0 & 3.3 & 16.4 & 16.4 & 296.1 & 7.3 & - & - & - & - & 0.7 & - \\
\hline 1.1 & 1.1 & 3.1 & 6.4 & 1.5 & 3.5 & 3.1 & 270.0 & 336.5 & 315.6 & 321.2 & 321.6 & - \\
\hline 43.3 & 180.5 & 32.9 & 30.7 & 586.4 & 672.9 & 20.3 & - & - & - & - & - & - \\
\hline 0.1 & - & 0.3 & 0.2 & 0.1 & 0.3 & 0.2 & 27.9 & 36.2 & 31.0 & 28.2 & 28.6 & - \\
\hline 0.1 & 0.1 & 0.2 & - & 0.2 & 0.1 & 0.1 & 9.8 & 13.7 & 11.3 & 10.7 & 10.1 & - \\
\hline- & - & - & 0.1 & 0.1 & 0.2 & - & 11.4 & 13.7 & 12.8 & 11.6 & 13.3 & - \\
\hline- & 0.1 & 0.2 & - & 0.2 & 0.6 & 0.2 & 38.5 & 52.3 & 45.7 & 40.6 & 42.1 & - \\
\hline 0.2 & 0.2 & 0.5 & 0.8 & 0.6 & 0.8 & 0.2 & 8.4 & 15.1 & 13.5 & 15.5 & 8.4 & - \\
\hline- & - & 0.1 & 0.1 & - & 0.1 & - & 4.3 & 5.5 & 4.7 & 4.7 & 4.5 & - \\
\hline 0.4 & 0.2 & 0.9 & 2.3 & 0.7 & 2.3 & 1.2 & 77.7 & 111.3 & 97.1 & 98.0 & 89.3 & - \\
\hline- & - & - & - & - & - & - & 1.6 & 1.8 & 1.7 & 1.8 & 1.4 & - \\
\hline 57.2 & 60.2 & 60.8 & 71.5 & 58.9 & 72.0 & 63.5 & 1.0 & 1.5 & 1.6 & 1.6 & 1.0 & - \\
\hline 0.3 & 0.3 & 0.9 & 1.7 & 0.5 & -0.2 & 1.0 & 241.4 & 301.9 & 279.6 & 259.1 & 263.3 & - \\
\hline 0.9 & 0.1 & 0.6 & 0.4 & 0.2 & 0.5 & 0.3 & 0.2 & 0.2 & 0.2 & 0.2 & 0.2 & - \\
\hline 0.1 & - & 0.3 & 0.5 & 0.1 & 0.4 & 0.2 & 46.5 & 59.4 & 55.9 & 53.2 & 54.1 & - \\
\hline 567.3 & 1091.7 & 679.3 & 488.5 & 2593.9 & 2651.9 & 736.2 & - & - & 0.1 & - & 0.1 & - \\
\hline 2.1 & 2.4 & 2.2 & 2.7 & 2.4 & 3.0 & 2.0 & 80.9 & 95.4 & 90.7 & 91.2 & 81.6 & - \\
\hline- & - & 0.2 & 0.3 & 0.2 & 0.3 & 0.2 & 49.5 & 66.7 & 60.8 & 53.5 & 57.7 & - \\
\hline 4.3 & 3.8 & 3.0 & 2.5 & 12.5 & 9.7 & 1.4 & 0.4 & 0.7 & 1.8 & 0.6 & 0.8 & - \\
\hline 1.8 & 1.7 & 1.8 & 2.5 & 2.0 & 2.2 & 2.2 & - & 0.1 & 0.2 & 0.2 & 0.1 & - \\
\hline- & - & - & - & - & 0.1 & - & 5.0 & 6.5 & 5.6 & 5.2 & 5.4 & - \\
\hline 0.1 & 0.1 & 0.2 & 0.6 & 0.1 & 0.1 & 0.2 & - & 0.1 & - & - & - & - \\
\hline- & - & - & - & - & - & - & 1.3 & 1.6 & 1.5 & 1.4 & 1.3 & - \\
\hline 0.1 & - & - & 0.1 & 0.1 & 0.1 & - & - & - & - & - & - & - \\
\hline 42.2 & 43.2 & 42.7 & 49.6 & 42.1 & 57.4 & 47.0 & 74.5 & 90.8 & 85.8 & 87.6 & 77.5 & - \\
\hline 0.5 & 0.7 & 1.3 & 1.4 & 1.6 & 1.8 & 0.7 & 96.8 & 126.5 & 110.2 & 100.7 & 101.3 & - \\
\hline 0.1 & 0.1 & 0.2 & 0.2 & 0.3 & - & 0.1 & 8.5 & 10.7 & 10.0 & 10.3 & 8.0 & - \\
\hline 535.5 & 511.2 & 476.4 & 413.8 & 403.0 & 473.9 & 448.4 & 202.0 & 187.6 & 218.3 & 208.8 & 206.0 & - \\
\hline 7.0 & 7.9 & 17.7 & 44.0 & 30.1 & 32.4 & 9.4 & 256.3 & 402.8 & 395.5 & 456.5 & 227.3 & - \\
\hline
\end{tabular}

The compositional zoning may have occurred within a horizontally layered magma chamber (Fridrich and Mahood, 1987), forming 2 major crystallizing discrete bodies ( $\mathrm{B}$ and $\mathrm{C}$ ), as reflected in their very similar compositions, but separated from each other by a major shift in between their compositional trends (Fig. 11, 13 and 16b). Internal compositional zoning within each major magma body have formed multiple incrementally zoned magma layers, as seen within the phenocryst composition in each flow units (Figs. 13 and 16c). Abnormal bulk rock compositions possibly indicate contamination of the magma by minor country-rock assimilation.

Intensity of alkali feldspar fractionation changed progressively, but no internal zoning is recorded in the phenocrysts. This indicates that they were constantly in equilibrium with the melt (White et al., 2003). The large range of Ba concentrations in the alkali feldspar of the same flow units remains unclear, and may be associated with the mobility of this element during post-depositional processes. Oxide and titanite did not fractionate at this stage, as $\mathrm{Fe}_{2} \mathrm{O}_{3}^{*}$ and $\mathrm{TiO}_{2}$ concentrations increase in bulk rock (Fig. 10). Compositional trends in alkali feldspars generally follow the bulk rock ones.

Batch A is compositionally very similar to batch B, except for its higher concentration of compatible elements. Its presence at the base of the stratigraphy, and large amount of titanite and haüyne phenocrysts suggest a small volume, highly fractionated (titanite, haüyne) magma chamber cupola (Fig. 16c). Petrologic modeling show that such REE loss could correspond to a Rayleigh fractionation involving 1.5 to $2 \%$ of titanite, although HREE, Y and Ta behavior could not be explained with titanite fractionation alone. Consequently, other processes might be involved, as e.g. fluid interaction, minor country rock assimilation, inclusions, wall-rock lithics and 

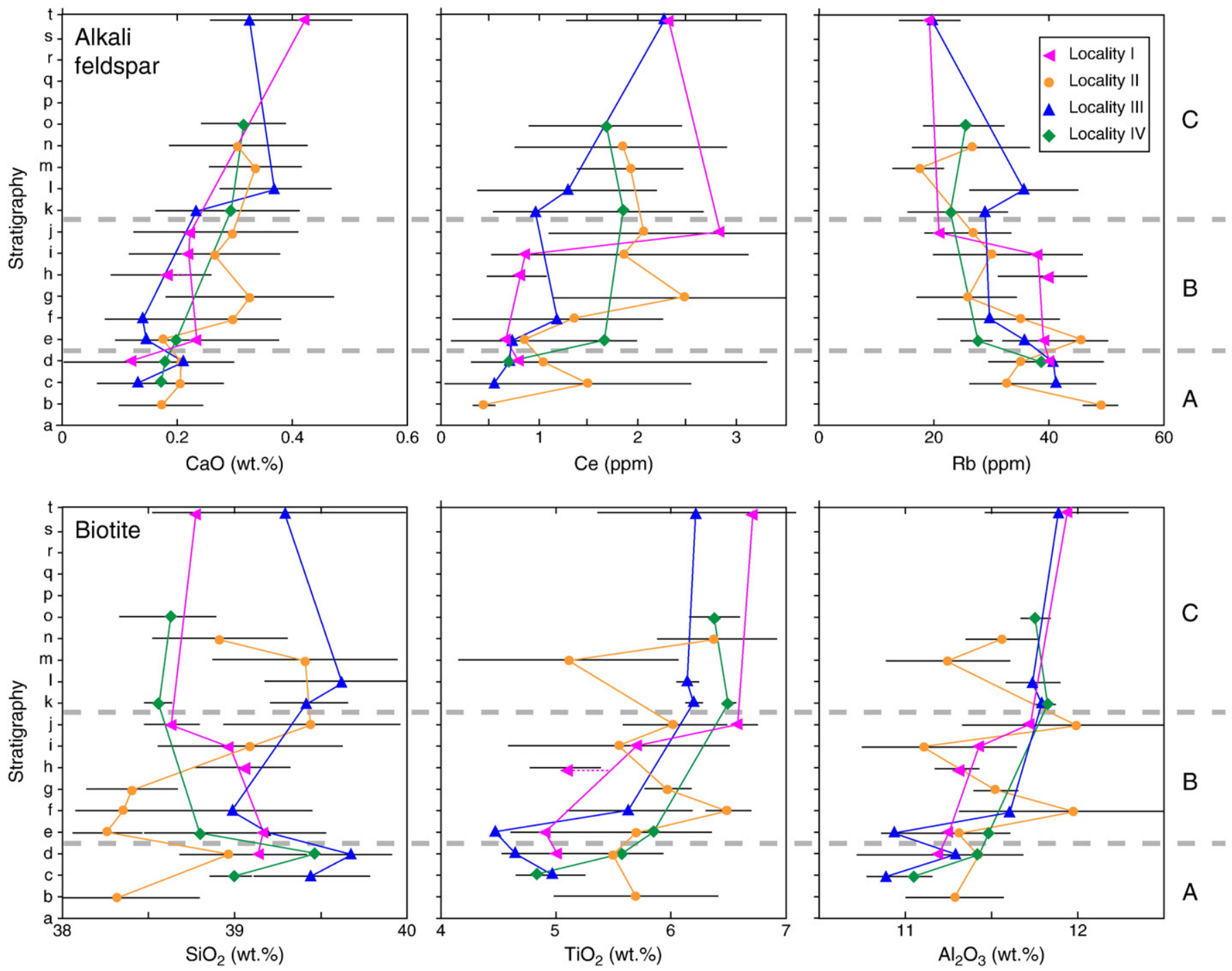

Fig. 13. Compositional trends of alkali feldspar and biotite along reconstituted stratigraphy of Ayagaures ignimbrite. Main compositional groups A, B and C.

fractionation of other accessory phenocrysts (allanite, monazite, etc.), as proposed by Troll et al. (2003) and Snyder et al. (2004). Chevkinite occurs in two Mogán Group ignimbrites and has a huge REE compatibility. Therefore, even if the mass of such accessory phases is very small, they act as a major "sink", especially in the LREE. Chevkinite crystals were, however, not found in AY and modeling of its fractionation using Mogán Group dataset does not match with AY composition.

\subsection{Magma chamber tapping}

The ignimbrite zonation is interpreted to mirror the sequential evacuation of the compositionally zoned magma bodies $\mathrm{A}, \mathrm{B}$, and $\mathrm{C}$ in an incremental fashion of up to 20 eruption pulses reflected in the flow units and the initial tephra fall (Fig. 16d). The similar bulk rock and phenocrysts compositions suggest that each flow unit has its specific composition that corresponds to a more or less identical portion in the zoned magma body. Incremental caldera collapse (Schmincke, 2004) may be in close association with the tapping and eruption of the successive flow units. Except when reversals occurred, tapping was probably migrating progressively down in the magma chamber, as reflected in the overall continuously reversed compositional zonation in the cooling unit stratigraphy (Fig. 16d).

\section{Conclusions}

AY represents the evolved part of a partially evacuated highly alkaline magma reservoir interpreted to have been compositionally zoned, but thermodynamically equilibrated. AY consists of up to 19 flow units, belonging to three magma batches ( $A, B$ and $C$ ), and were mainly identified by their compositional signature and clast modal amount. Bulk rock major elements show little compositional zoning, contrary to strong compositional gradients in the trace elements, corresponding to a cryptic zoning, common in peralkaline magma chambers (Wolff and Storey, 1984). Feldspar and biotite phenocrysts compositions reflect the incremental compositional zoning found in the bulk rock.

$\mathrm{AY}$ is interpreted to have issued from a homogeneous magma body, initially created by addition and efficient mixing of multiple batches. Separation of the initial magma body into shallow level layered batches is suggested by their very similar bulk rock and phenocryst composition. A quasi steady-state equilibrium was reached prior to a major episode of crystallization of unzoned alkali feldspar and biotite phenocrysts. Resulting bulk rock and phenocryst 


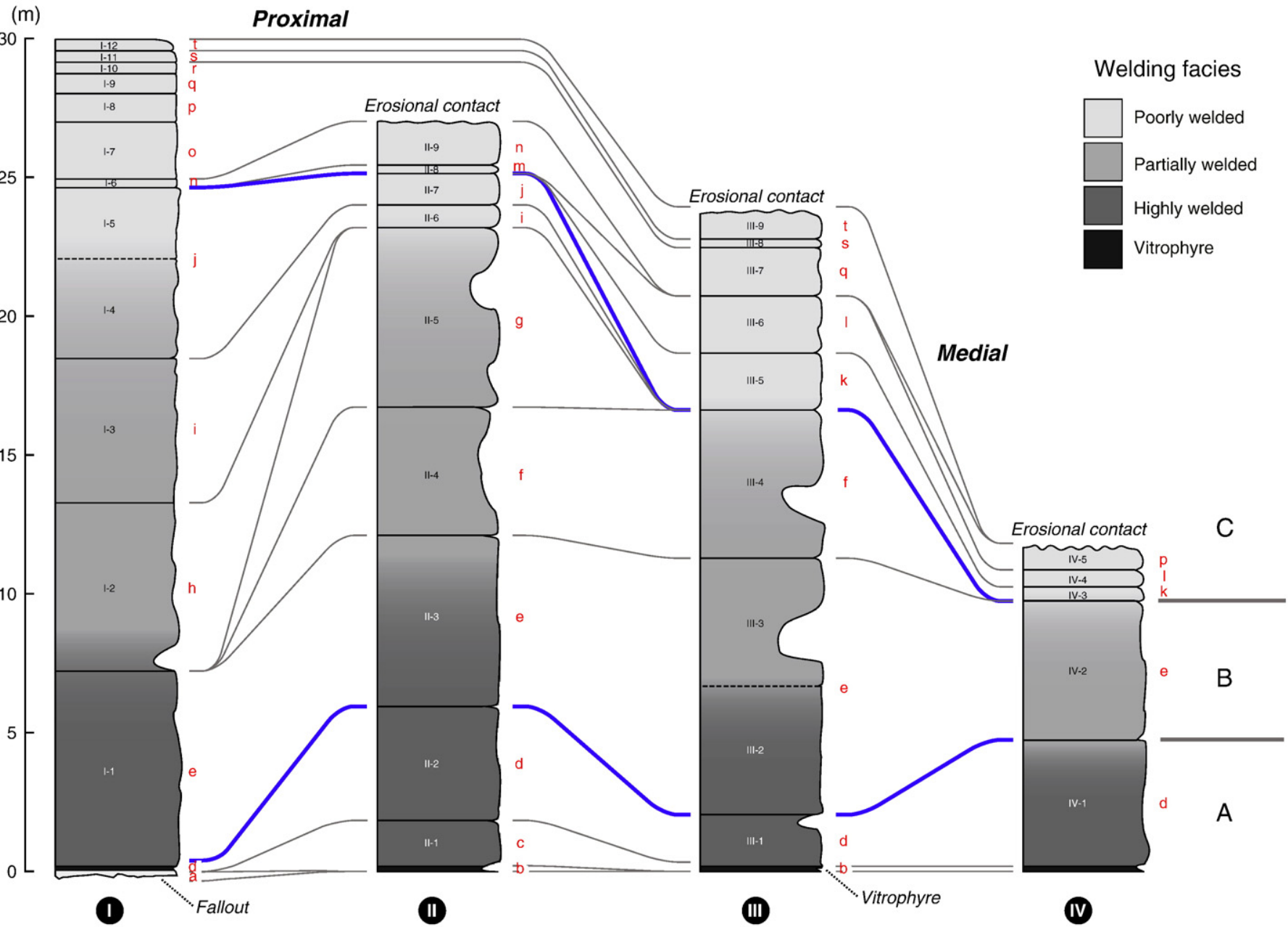

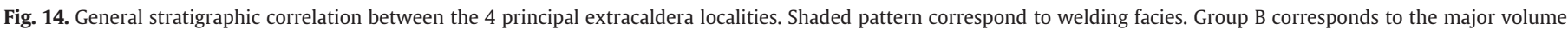

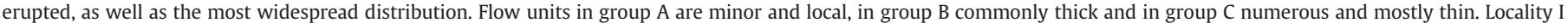
suffered minor erosion in contrast to localities II and IV. Layer numbers are relative to local flow unit name, letters to regional names.

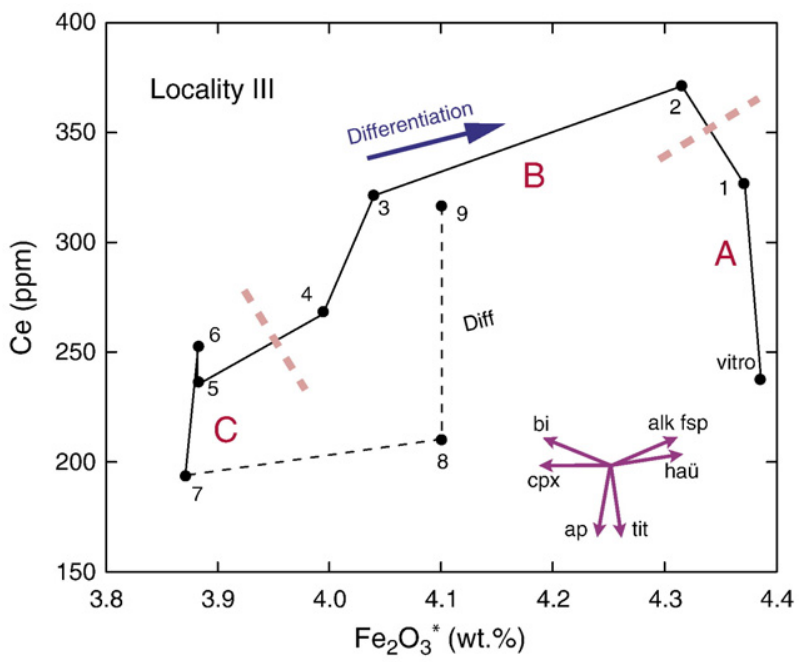

Fig. 15. Fractionation trends in a Ce vs. $\mathrm{Fe}_{2} \mathrm{O}_{3}^{*}$ diagram of bulk rock and fiamme shows a complex fractionation system, dominated by feldspar (group B) and titanite (group A). Arrows indicates the direction of bulk rock and fiamme evolution upon fractionation of the crystal phase. Main compositional groups A, B and C. Fsp: alkali feldspar; bi: biotite; cpx: clinopyroxene; tit: titanite, haü: haüyne. composition indicates zoning of the magma chamber into three major magma batches (A, B and C) internally zoned in incremental fashion. The small volume, highly fractionated magma chamber cupola (body A) is evidenced by significant amount of titanite and haüyne phenocrysts in basal flow units and in a locally preserved, highly evolved fallout tephra.

Progressive downward tapping of the reservoir was controlled by incremental caldera collapse (Schmincke, 2004). Unzoned phenocrysts, incremental zoning of the cooling unit and evacuation reversals show that mingling/mixing was strongly restricted following separation into the magma bodies.

Packages of erupted flow units correspond to different magma bodies implying a potential modification of the eruption (time break and/or eruptive site) in between the deposition of the major compositional groups A, B and C. Eruption products were mostly deposited as pyroclastic density currents. Stratigraphic reconstruction in the field and chemical composition characterized at least 19 flow units with a local or a widespread extent in southern and western GC, covering a locally preserved initial fallout. Including widespread mantling of the whole island and tentatively identified submarine distal equivalent, the total erupted magma volume is estimated at $>50 \mathrm{~km}^{3}$.

The single cooling unit is compacted and made up of 4 gradational welding facies: vitrophyre, highly welded, partially welded and finally poorly welded. The entire cooling unit was affected by deuteric alteration, characterized by devitrification and crystallization in a microcrystalline matrix. 
Table 3

Morphological and compositional characteristics of the flow unit packages.

\begin{tabular}{|c|c|c|c|}
\hline & Group A - flow units a-d & Group B - flow units $\mathrm{e}-\mathrm{j}$ & Group C - flow units k-t \\
\hline Thickness & $<5 \mathrm{~m}$ & $>5 \mathrm{~m}$ & $<2 \mathrm{~m}$ \\
\hline Number & Few $(<3)$ & Numerous (6) & Numerous (10) \\
\hline Distribution & Fallout and sector oriented flows & Widespread flows & Widespread and sector-oriented flows \\
\hline Alkali feldspar, vol.\% amount & 6 to $9 \%$ & Gradual increase, 7 to $18 \%$ & Usually 9 to $13 \%$ \\
\hline Titanite occurrence & Very rich ( $>20$ crystals per t.s) & Rich ( 5 per t.s $)$ & Generally absent ( $<2$ per t.s) \\
\hline Haüyne occurrence & Rich (5-10 crystals per t.s) & Progressive decrease (4-6 per t.s.) & Nearly absent $(<3$ per t.s. $)$ \\
\hline Clinopyroxene occurrence & Rich (5-7 crystals per t.s) & Rich and decrease ( $4-14$ per t.s.) & Commonly absent \\
\hline Crystal fractionation trend & REE-rich crystals (titanite) fractionation decreasing & Feldspar fractionation decreasing & Unchanged trend \\
\hline
\end{tabular}
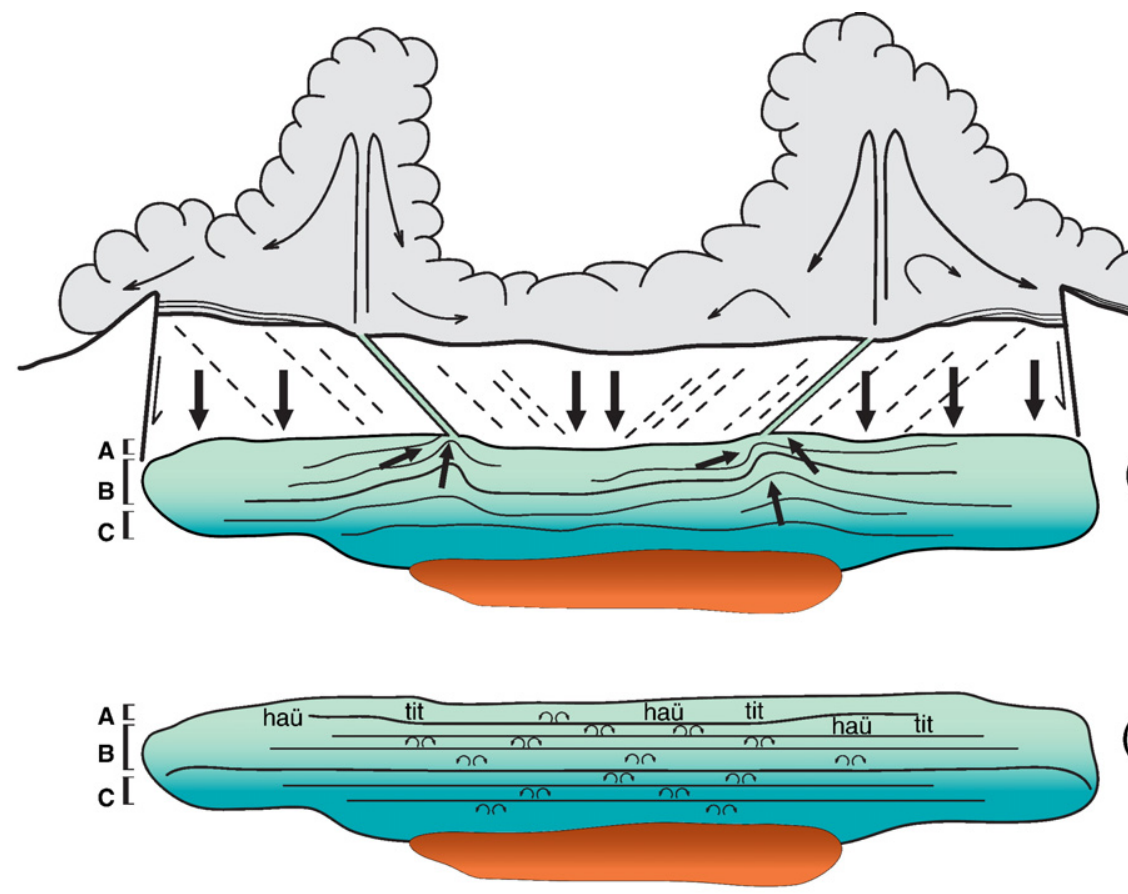

(c) Formation of the top cupola Incremental zoning of the magma bodies

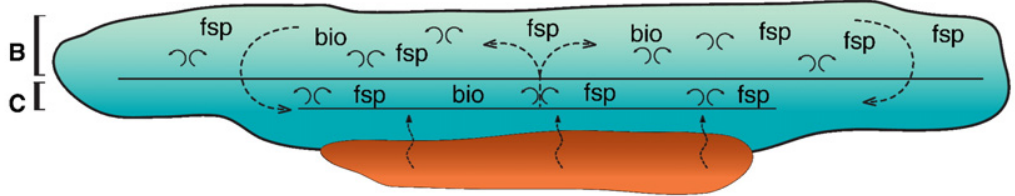

(b) Magma body at quasi steady-state equilibrium Separation into 2 major bodies Stage of dominant crystallization

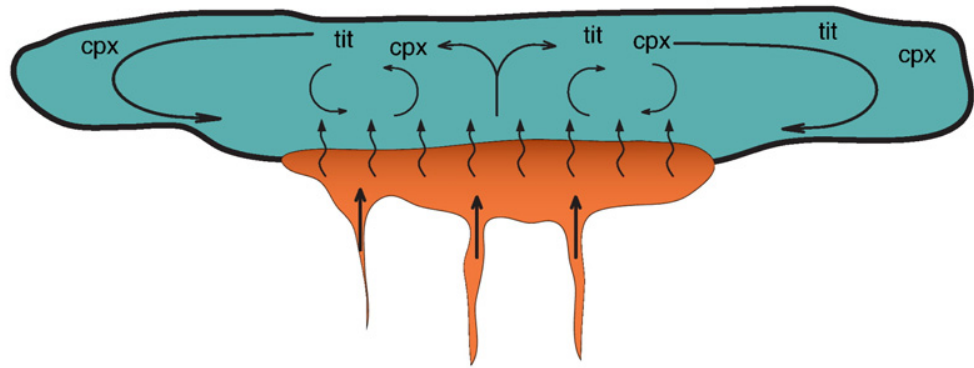

(a) New magma input Intense convection

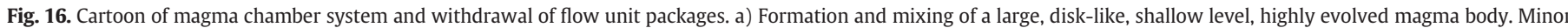

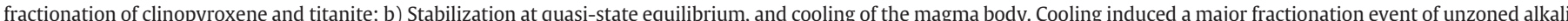

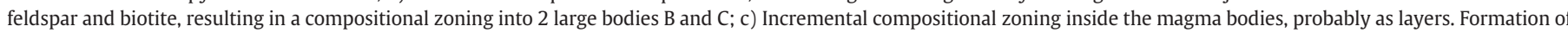

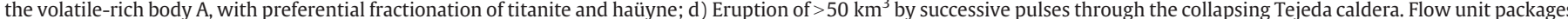

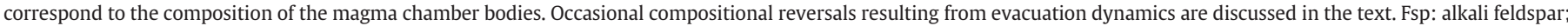

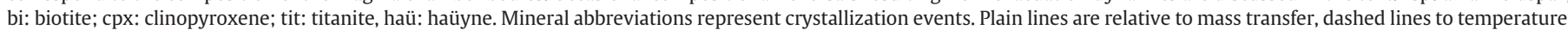
Cone sheet complex (Schirnick et al., 1999) is represented by bold dashed lines. 


\section{Acknowledgements}

This work is a part of the M.Sc. thesis of MJ at the University of Lausanne, Switzerland. F. Bussy and H-R. Pfeifer are thanked for their help in several laboratories. Wes Hildreth, Jocelyn McPhie, Setsuya Nakada, Fukashi Maeno and Susan Belford made helpful comments on earlier drafts of the manuscript. The manuscript benefited greatly from the thorough reviews of Judy Fierstein, Martin Streck and Armin Freundt. MJ thanks the Swiss foundations "Agassiz" and "Société Académique Vaudoise", for partial support. The work by HUS and MS was supported by grant Schm 250/82-1 by the Deutsche Forschungsgemeinschaft.

\section{Appendix A. Supplementary data}

Supplementary data associated with this article can be found, in the online version, at doi:10.1016/j.jvolgeores.2010.07.002.

\section{References}

Ablay, G.J., Ernst, G.G.J., Marti, J., Sparks, R.S.J., 1995. The 2 ka subplinian eruption of Montaña Blanca, Tenerife. Bull. Volcanol. 57, 337-355.

Ablay, G.J., Carroll, M.R., Palmer, M.R., Marti, J., Sparks, R.S.J., 1998. Basanite-phonolite lineages of the Teide-Pico Viejo volcanic complex, Tenerife, Canary Islands. J. Petrol. 39, 905-936.

Allen, S.R., McPhie, J., 2003. Phenocryst fragments in rhyolitic lavas and lava domes. J. Volcanol. Geotherm. Res. 126, 263-283.

Blake, S., Ivey, G.N., 1986. Magma-mixing and the dynamics of withdrawal from stratified reservoirs. J. Volcanol. Geotherm. Res. 27, 153-178.

Bryan, S.E., 2006. Petrology and geochemistry of the quaternary caldera-forming, phonolitic Granadilla eruption, Tenerife (Canary Islands). J. Petrol. 47, 1557-1589.

Freundt, A., Schmincke, H.U., 1995a. Eruption and emplacement of a basaltic welded ignimbrite during caldera formation on Gran Canaria. Bull. Volcanol. 56, 640-659.

Freundt, A., Schmincke, H.U., 1995b. Petrogenesis of rhyolite-trachyte-basalt composite ignimbrite P1, Gran Canaria, Canary Islands. J. Geophys. Res. 100, 455-474. doi:10.1029/94JB02478.

Freundt, A., Tait, S.R., 1986. The entrainment of high-viscosity magma into low-viscosity magma in eruption conduits. Bull. Volcanol. 48, 325-339.

Fridrich, C.J., Mahood, G.A., 1987. Compositional layers in the zoned magma chamber of the Grizzly Peak Tuff. Geology 15, 299-303.

Guo, J., Green, T.H., 1989. Barium partitioning between alkali feldspar and silicate liquid at high temperature and pressure. Contrib. Mineral. Petrol. 102, 328-335.

Hildreth, W., 1981. Gradients in silicic magma chambers: implications for lithospheric magmatism. J. Geophys. Res. 86, 10153-10192. doi:10.1029/JB086iB11p10153.

Hildreth, W., 1983. The compositionally zoned eruption of 1912 in the Valley of Ten Thousand Smokes, Katmai National Park, Alaska ( USA). J. Volcanol. Geotherm. Res. $18,1-56$

Hildreth, W., Mahood, G., 1985. Correlation of ash-flow tuffs. Geol. Soc. Am. Bull. 96, 968-974.

Hildreth, W., Wilson, C.J.N., 2007. Compositional zoning of the bishop tuff. J. Petrol. 48, 951-999.

Kobberger, G., Schmincke, H.U., 1999. Deposition of rheomorphic ignimbrite D (Mogán Formation), Gran Canaria, Canary Islands, Spain. Bull. Volcanol. 60, 465-485.

Krastel, S., Schmincke, H.U., 2002. Crustal structure of northern Gran Canaria, Canary Islands, deduced from active seismic tomography. J. Volcanol. Geotherm. Res. 115, 153-177.
Le Bas, M.J., Le Maitre, R.W., Streckeisen, A., Zanettin, B., 1986. A chemical classification of volcanic rocks based on the total alkali-silica diagram. J. Petrol. 27, 745-750.

Morimoto, N., et al., 1988. Nomenclature of pyroxenes. Mineral. Petrol. 39, 55-76.

Schirnick, C., Van Den Bogaard, P., Schmincke, H.-U., 1999. Cone sheet formation and intrusive growth of an oceanic island-the Miocene Tejeda complex on Gran Canaria (Canary Islands). Geology 27, 207-210.

Schmincke, H.-U., 1969. Ignimbrite sequence on Gran Canaria. Bull. Volcanol. 33, 1199-1219.

Schmincke, H.-U., 1976. The Geology of the Canary Islands. Dr. W. Junk Publ, The Hague Netherlands (NLD).

Schmincke, H.-U., 1982. Volcanic and Chemical Evolution of the Canary Islands. In: von Rad, U., Hinz, K., Sarnthein, M., Seibold, E. (Eds.), Geology of the Northwest African continental margin. Springer-Verlag, Berlin, pp. 273-306.

Schmincke, H.-U., 1987. Geological field guide of Gran Canaria. Pluto Press, Witten. 179 pp.

Schmincke, H.-U., 2004. Volcanism. Springer-Verlag. 324 pp.

Schmincke, H.-U., Sumita, M., 1998a. Tephra event stratigraphy and emplacement of volcaniclastic sediments, Mogán and Fataga stratigraphic intervals, part II: Origin and emplacement of volcaniclastic layers. Proc. Ocean Drill. Program Part B Sci. Results 157, 267-291.

Schmincke, H.-U., Sumita, M., 1998b. Volcanic evolution of Gran Canaria reconstructed from apron sediments: Synthesis of Vicap Project drilling. Proc. Ocean Drill. Program Part B Sci. Results 157, 443-469.

Schmincke, H.-U., Sumita, M., 2004. Gran Canaria Geological Field Guide. Pluto Press, Asheberg, Germany.

Schmincke, H.-U., Sumita, M., 2010. Geological evolution of the Canary Islands. Görres Verlag. 188 pp.

Schmincke, H.-U., Swanson, D.A., 1967. Laminar viscous flowage structures in ash-flow tuffs from Gran Canaria Canary Islands. J. Geol. 75, 641-664.

Smith, R.L., 1960. Ash flows. Geol. Soc. Am. Bull. 71, 795-842.

Smith, R.L., 1979. Ash-flow magmatism; ash-flow tuffs. Spec. Pap. - Geol. Soc. Am. 180, $5-27$.

Snyder, D.C., Widom, E., Pietruszka, A.J., Carlson, R.W., 2004. The role of open-system processes in the development of silicic magma chambers: A chemical and isotopic investigation of the Fogo A trachyte deposit, Sáo Miguel, Azores. J. Petrol. 45, 723-738.

Streck, M.J., Grunder, A.L., 1995. Crystallization and welding variations in a widespread ignimbrite sheet; the Rattlesnake Tuff, eastern Oregon, USA. Bull. Volcanol. 57, 151-169.

Sumita, M., Schmincke, H.U., 1998. Tephra event stratigraphy and emplacement of volcaniclastic sediments, Mogán and Fataga stratigraphic intervals, part I: Mineral and chemical stratigraphy of volcaniclastic units and correlation to the subaerial record. Proc. Ocean Drill. Program Part B Sci. Results 157, 219-266.

Sun, S.S., McDonough, W.F. 1989. Chemical and Isotopic Systematics of Oceanic Basalts: Implications for Mantle Composition and Processes. In: Saunders, A.D., Norry, M.J. (Eds.), Magmatism in the ocean basins. Blackwell Scientific; Geological Society Special Publication, pp. 313-345.

Troll, V.R., Schmincke, H.U., 2002. Magma mixing and crustal recycling recorded in ternary feldspar from compositionally zoned peralkaline Ignimbrite 'A', Gran Canaria, Canary Islands. J. Petrol. 43, 243-270.

Troll, V.R., Sachs, P.M., Schmincke, H.U., Sumita, M., 2003. The REE-Ti mineral chevkinite in comenditic magmas from Gran Canaria, Spain: A SYXRF-probe study. Contrib. Mineral. Petrol. 145, 730-741.

White, J.C., Holt, G.S., Parker, D.F., Ren, M., 2003. Trace-element partitioning between alkali feldspar and peralkalic quartz trachyte to rhyolite magma. Part I: systematics of trace-element partitioning. Am. Mineral. 88, 316-329.

Wilson, C.J.N., Hildreth, W., 2003. Assembling an ignimbrite: mechanical and thermal building blocks in the Bishop Tuff, California. J. Geol. 111, 653-670.

Wolff, J.A., Storey, M., 1984. Zoning in highly alkaline magma bodies. Geol. Mag. 121, 563-575.

Wolff, J.A., Grandy, J.S., Larson, P.B., 2000. Interaction of mantle-derived magma with island crust? Trace element and oxygen isotope data from the Diego Hernandez Formation, Las Canadas, Tenerife. J. Volcanol. Geotherm. Res. 103, 343-366. 